\title{
Synthesis of ent-Haterumalide NA (Oocydin A) Methyl Ester
}

\author{
Yonghong Gu and Barry B. Snider*
}

Department of Chemistry MS 015, Brandeis University, Waltham, MA 02454-9110

Experimental Section Pages S1-S21

NMR Spectra Pages S22-S63

\section{Experimental Procedures}

General Procedures. NMR spectra were recorded at $400 \mathrm{MHz}$, chemical shifts are reported in $\delta$, and coupling constants are reported in Hz. IR spectra were obtained as thin films and are reported in $\mathrm{cm}^{-1}$.

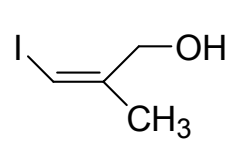

7

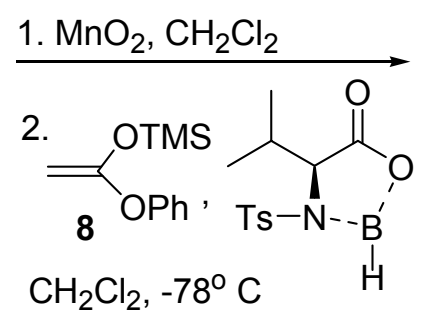

$65 \% 2$ steps, $80 \%$ ee

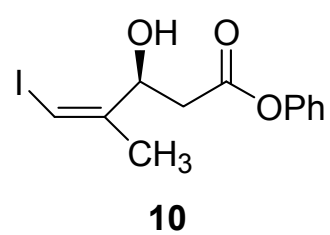

10

Phenyl (3S)-3-Hydroxy-5-iodo-4-methyl-4Z-pentenoate (10). $\mathrm{MnO}_{2}(6.0 \mathrm{~g}$, $60.6 \mathrm{mmol})$ was added to a solution of iodoalkenol $7^{9}(0.60 \mathrm{~g}, 3.03 \mathrm{mmol})$ in dry $\mathrm{CH}_{2} \mathrm{Cl}_{2}$ $(30 \mathrm{~mL})$, the reaction mixture was stirred at room temperature for $2 \mathrm{~h}$ and filtered. The filtrate was concentrated to give the very unstable aldehyde, ${ }^{10}$ which was immediately used in next step.

$\mathrm{BH}_{3} \cdot \mathrm{THF}(1.0 \mathrm{M}$ in THF, $3.03 \mathrm{~mL}, 3.03 \mathrm{mmol})$ was added dropwise to a solution of $N$-Ts-L-valine ${ }^{22}(0.724 \mathrm{~g}, 3.33 \mathrm{mmol})$ in dry $\mathrm{CH}_{2} \mathrm{Cl}_{2}(5 \mathrm{~mL})$ at $0{ }^{\circ} \mathrm{C}$ under $\mathrm{N}_{2}$. The reaction mixture was allowed to stir for $30 \mathrm{~min}$ at $0{ }^{\circ} \mathrm{C}$ and an additional $30 \mathrm{~min}$ at room temperature and cooled to $-78{ }^{\circ} \mathrm{C}$. A solution of the above aldehyde in $\mathrm{CH}_{2} \mathrm{Cl}_{2}(3 \mathrm{~mL})$ was added slowly over 5 min and the solution was stirred for $5 \mathrm{~min}$. Silyl ketene acetal $\mathbf{8}^{23}(0.69 \mathrm{~g}, 3.33 \mathrm{mmol})$ was added over $5 \mathrm{~min}$. The reaction mixture was stirred at $-78^{\circ} \mathrm{C}$ for $4 \mathrm{~h}$. The reaction was quenched at $78{ }^{\circ} \mathrm{C}$ by adding saturated $\mathrm{NaHCO}_{3}(30 \mathrm{~mL})$ and the aqueous layer was extracted with $\mathrm{CH}_{2} \mathrm{Cl}_{2}$ 
$(3 \times 20 \mathrm{~mL})$. The combined organic layers were dried over $\mathrm{MgSO}_{4}$ and concentrated. Flash chromatography of the residue on silica gel (25:1 hexanes/EtOAc) gave $0.653 \mathrm{~g}(65 \%, 80 \%$ ee, Chiralpak AD, 9:1 hexanes/2-propanol, $1.0 \mathrm{~mL} / \mathrm{min}, \lambda 254 \mathrm{~nm}, t_{\mathrm{R}}=8.8 \mathrm{~min}$, (S, major isomer), $t_{\mathrm{R}}=11.5 \mathrm{~min},(\mathrm{R}$, minor isomer) $)$ of alcohol 10: ${ }^{1} \mathrm{H}$ NMR $7.40(\mathrm{dd}, 2, J=7.9,7.3), 7.26(\mathrm{t}, 1$, $J=7.9), 7.12(\mathrm{~d}, 2, J=7.3), 6.06(\mathrm{q}, 1, J=1.2), 5.13(\mathrm{ddd}, 1, J=9.8,3.7,3.1), 2.86(\mathrm{dd}, 1$, $J=16.5,9.8), 2.85(\mathrm{~d}, 1, J=3.1, \mathrm{OH}), 2.76(\mathrm{dd}, 1, J=16.5,3.7), 1.95(\mathrm{~d}, 3, J=1.2) ;{ }^{13} \mathrm{C} \mathrm{NMR}$ $170.5,150.3,146.7,129.5$ (2 C), 126.1, 121.5 (2 C), 75.2, 72.6, 38.8, 19.0; IR 3459, 1748; $[\alpha]^{20}{ }_{\mathrm{D}}-15.9\left(\mathrm{c} 1.32, \mathrm{CHCl}_{3}\right)$; HRMS $\left(\mathrm{CI} / \mathrm{NH}_{3}\right)$ calculated for $\mathrm{C}_{12} \mathrm{H}_{17} \mathrm{NO}_{3} \mathrm{I}\left(\mathrm{MNH}_{4}{ }^{+}\right)$350.0253, found 350.0240 .

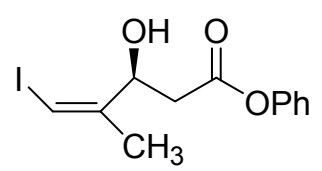

10

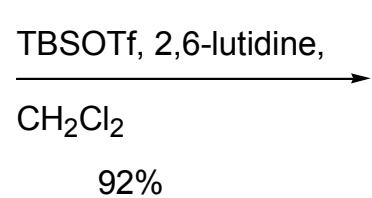

$92 \%$

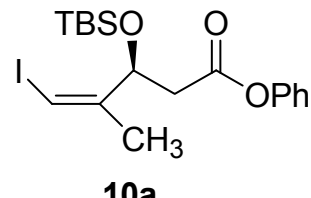

$10 \mathrm{a}$

\section{Phenyl (3S)-3-t-Butyldimethylsilyloxy-5-iodo-4-methyl-4Z-pentenoate (10a).}

TBSOTf $(0.368 \mathrm{~g}, 1.39 \mathrm{mmol})$ was added to a solution of alcohol $10(0.257 \mathrm{~g}, 0.774 \mathrm{mmol})$ and 2,6-lutidine $(0.315 \mathrm{~g}, 2.94 \mathrm{mmol})$ in $\mathrm{CH}_{2} \mathrm{Cl}_{2}(3 \mathrm{~mL})$ at $0{ }^{\circ} \mathrm{C}$. The reaction mixture was stirred at room temperature for $1 \mathrm{~h}$. The reaction was quenched with $\mathrm{H}_{2} \mathrm{O}(10 \mathrm{~mL})$ and the aqueous layer was extracted with $\mathrm{CH}_{2} \mathrm{Cl}_{2}(3 \times 10 \mathrm{~mL})$. The combined organic layers were dried over $\mathrm{MgSO}_{4}$ and concentrated. Flash chromatography of the residue on silica gel (50:1 hexanes/EtOAc) gave $0.317 \mathrm{~g}(92 \%)$ of 10a: ${ }^{1} \mathrm{H}$ NMR $7.38(\mathrm{dd}, 2, J=8.5,7.3), 7.23(\mathrm{t}, 1, J=7.3), 7.11(\mathrm{~d}, 2$, $J=8.5), 5.99(\mathrm{~s}, 1), 5.19(\mathrm{dd}, 1 J=9.2,4.3), 2.83(\mathrm{dd}, 1, J=14.7,9.2), 2.61(\mathrm{dd}, 1, J=14.7$, 4.3), 1.92 (s, 3), 0.90 (s, 9), 0.13 (s, 3), 0.07 (s, 3); ${ }^{13} \mathrm{C}$ NMR 168.8, 150.7, 147.7, 129.4 (2 C), 125.8, 121.5 (2 C), 74.3, 73.9, 41.0, 25.7 (3 C), 18.7, 18.0, -4.8, -5.0; IR 1764, 1594; $[\alpha]^{20}{ }_{\mathrm{D}}+15.6\left(\mathrm{c} 1.50, \mathrm{CHCl}_{3}\right) ; \mathrm{HRMS}\left(\mathrm{CI} / \mathrm{NH}_{3}\right)$ calculated for $\mathrm{C}_{18} \mathrm{H}_{28} \mathrm{IO}_{3} \mathrm{Si}\left(\mathrm{MH}^{+}\right) 447.0853$, found 447.0835 . 
<smiles>C/C(=C/I)[C@H](CC(=O)Oc1ccccc1)Oc1ccccc1</smiles>

$10 \mathrm{a}$

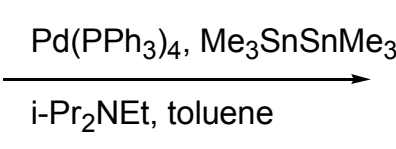

$91 \%$

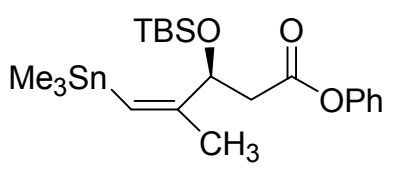

$4 \mathbf{a}$

\section{Phenyl (3S)-3-t-Butyldimethylsilyloxy-4-methyl-5-trimethylstannyl-4Z-pentenoate}

(4a). $\mathrm{Me}_{3} \mathrm{SnSnMe}_{3}(0.440 \mathrm{~g}, 1.34 \mathrm{mmol})$ was added to a solution of vinyl iodide 10a $(0.200 \mathrm{~g}$, $0.448 \mathrm{mmol}), i$-Pr $2 \mathrm{NEt}(0.0116 \mathrm{~g}, 0.0897 \mathrm{mmol})$ and $\mathrm{Pd}\left(\mathrm{PPh}_{3}\right)_{4}(0.0518 \mathrm{~g}, 0.0448 \mathrm{mmol})$ in toluene $(3 \mathrm{~mL})$ at room temperature. The reaction mixture was heated in an $80{ }^{\circ} \mathrm{C}$ oil bath for 30 min. The reaction was quenched with $\mathrm{H}_{2} \mathrm{O}(5 \mathrm{~mL})$ and the aqueous layer was extracted with $\mathrm{Et}_{2} \mathrm{O}(3 \times 5 \mathrm{~mL})$. The combined organic layers were dried over $\mathrm{MgSO}_{4}$ and concentrated. Flash chromatography of the residue on Florisil (hexanes with $\left.3 \% \mathrm{Et}_{3} \mathrm{~N}\right)$ gave $0.200 \mathrm{~g}(91 \%)$ of $4 \mathbf{a}$ containing 10-20\% $\mathrm{Ph}_{3} \mathrm{P} .{ }^{1} \mathrm{H}$ NMR 7.39-7.09 (m, 5), 5.63 (s, 1), 4.75 (dd, 1, $J=9.8,3.1$ ), 2.91 $(\mathrm{dd}, 1, J=14.7,9.8), 2.53(\mathrm{dd}, 1, J=14.7,3.1), 1.92(\mathrm{~d}, 3, J=1.8), 0.89(\mathrm{~s}, 9), 0.21(\mathrm{~s}, 9), 0.07$ (s, 3), 0.04 (s, 3); ${ }^{13} \mathrm{C}$ NMR 169.5, 155.9, 150.7, 129.3 (2 C), 125.7, 125.4, 121.5 (2 C), 75.0, 43.3, 25.7 (3 C), 20.3, 18.0, -4.7, -5.1, -8.6 (3 C); IR 1763, 1594; $[\alpha]^{20}{ }_{\mathrm{D}}+1.8$ (c 1.0, $\mathrm{CHCl}_{3}$ ); HRMS (CI/NH$)$ calculated for $\mathrm{C}_{21} \mathrm{H}_{37} \mathrm{O}_{3} \mathrm{SiSn}\left(\mathrm{MH}^{+}\right)$485.1534, found, 485.1512 .
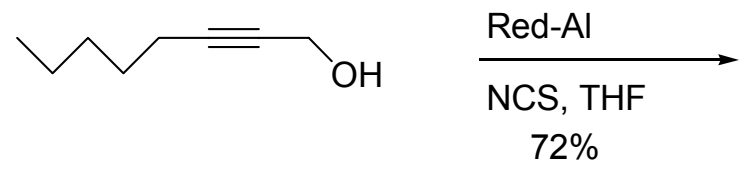

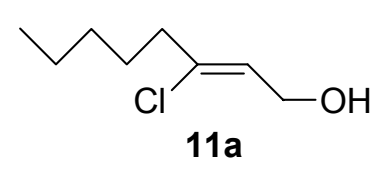

$11 \mathrm{a}$

3-Chloro-2Z-octen-1-ol (11a). Red-Al (1.21 mL, $4.0 \mathrm{mmol})$ was added slowly to a solution of 2-octyn-1-ol $(0.315 \mathrm{~g}, 2.5 \mathrm{mmol})$ in THF $(15 \mathrm{~mL})$ at room temperature. The resulting mixture was stirred at room temperature for $8 \mathrm{~h}$ and cooled to $-78^{\circ} \mathrm{C}$. A solution of $N$ chlorosuccinimide $(1.0 \mathrm{~g}, 7.5 \mathrm{mmol})$ in THF $(15 \mathrm{~mL})$ was added and the resulting mixture was slowly warmed to room temperature overnight. The reaction was quenched with saturated $\mathrm{NH}_{4} \mathrm{Cl}(10 \mathrm{~mL})$ and the aqueous layer was extracted with $\mathrm{Et}_{2} \mathrm{O}(3 \times 10 \mathrm{~mL})$. The combined organic layers were dried over $\mathrm{MgSO}_{4}$ and concentrated. Flash chromatography of the residue 
on silica gel (25:1 hexanes/EtOAc) gave $0.261 \mathrm{~g}(72 \%)$ of 11a: ${ }^{1} \mathrm{H}$ NMR $5.72(\mathrm{t}, 1, J=6.1)$, $4.30(\mathrm{~d}, 2, J=6.1), 2.33(\mathrm{t}, 2, J=7.9), 1.60-1.53(\mathrm{~m}, 2), 1.40-1.24(\mathrm{~m}, 4), 0.90(\mathrm{t}, 3, J=6.7)$.
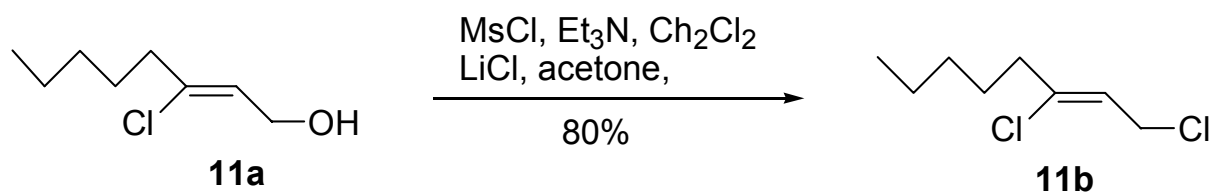

1,3-Dichloro-2Z-octene (11b). $\mathrm{MsCl}$ (0.288 g, $2.51 \mathrm{mmol})$ was added slowly to a solution of alcohol 11a $(0.240 \mathrm{~g}, 1.477 \mathrm{mmol})$ and $\mathrm{Et}_{3} \mathrm{~N}(0.187 \mathrm{~g}, 1.846 \mathrm{mmol})$ in dry $\mathrm{CH}_{2} \mathrm{Cl}_{2}$ $(5 \mathrm{~mL})$ at $0{ }^{\circ} \mathrm{C}$. The reaction was stirred for $20 \mathrm{~min}$ at $0{ }^{\circ} \mathrm{C}$, a solution of $\mathrm{LiCl}(0.626 \mathrm{~g}$, $14.77 \mathrm{mmol})$ in acetone $(5 \mathrm{~mL})$ was added. The resulting mixture was stirred at room temperature for $6 \mathrm{~h}$. The reaction was quenched with saturated $\mathrm{NH}_{4} \mathrm{Cl}(10 \mathrm{~mL})$ and the aqueous layer was extracted with $\mathrm{CH}_{2} \mathrm{Cl}_{2}(3 \times 10 \mathrm{~mL})$. The combined organic layers were dried over $\mathrm{MgSO}_{4}$ and concentrated. Flash chromatography of the residue on silica gel (hexane) gave $0.214 \mathrm{~g}(80 \%)$ of $11 \mathrm{~b}:{ }^{1} \mathrm{H}$ NMR $5.72(\mathrm{t}, 1, J=7.3), 4.20(\mathrm{~d}, 2, J=7.3), 2.36(\mathrm{t}, 2, J=7.3), 1.61$ $1.53(\mathrm{~m}, 2), 1.35-1.26(\mathrm{~m}, 4), 0.90(\mathrm{t}, 3, J=6.7)$.

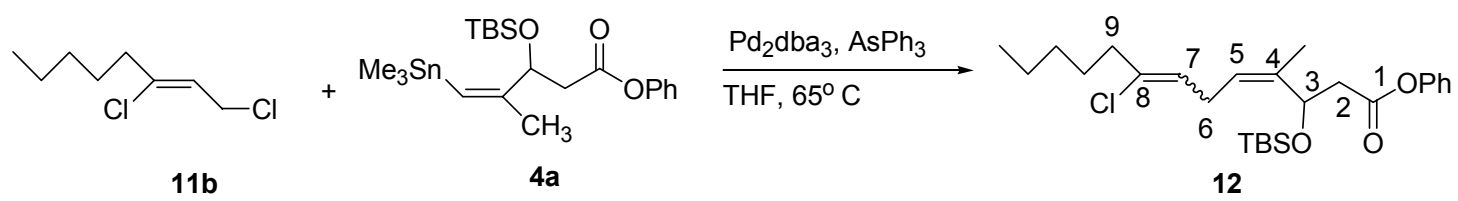

Phenyl (3S)-3-(t-Butyldimethylsilyloxy)-8-Chloro-4-methyl-4Z,7Z-tridecadienoate

(12). $\mathrm{AsPh}_{3}(5.1 \mathrm{mg}, 0.0166 \mathrm{mmol})$ and $\mathrm{Pd}_{2} \mathrm{dba}_{3}(3.8 \mathrm{mg}, 4.15 \mu \mathrm{mol})$ were added to a solution of allylic chloride $\mathbf{1 1 b}(26.3 \mathrm{mg}, 0.083 \mathrm{mmol})$ in dry THF $(0.5 \mathrm{~mL})$ at room temperature. The reaction was stirred at room temperature for $10 \mathrm{~min}$ and a solution of vinyltin $\mathbf{4 a}$ (40 $\mathrm{mg}$, $0.083 \mathrm{mmol})$ in THF $(0.5 \mathrm{~mL})$ was added. The reaction mixture was heated at $65^{\circ} \mathrm{C}$ for $19 \mathrm{~h}$ and concentrated. Flash chromatography of the residue on silica gel (hexane) gave $8 \mathrm{mg}$ of a 1:1 mixture of (7E)-and (7Z)-12 followed by $27 \mathrm{mg}(70 \%)$ of (7Z)-12.

Data for (7Z)-12: ${ }^{1} \mathrm{H}$ NMR 7.39-7.02 (m, 5), $5.39(\mathrm{dd}, 1, J=6.7,6.7)$; 5.22-5.18 (m, 2), 3.07-2.90 (m, 2), $2.89(\mathrm{dd}, 1, J=14.7,8.5), 2.58(\mathrm{dd}, 1, J=14.7,4.9), 2.27(\mathrm{t}, 2, J=7.3), 1.75$ 
$(\mathrm{s}, 3), 1.56-1.48(\mathrm{~m}, 2), 1.32-1.23(\mathrm{~m}, 4), 0.90(\mathrm{t}, 3, J=6.7), 0.88(\mathrm{~s}, 9), 0.08(\mathrm{~s}, 3), 0.04(\mathrm{~s}, 3)$.

The stereochemistry of $(\boldsymbol{Z}) \mathbf{- 1 2}$ was established by a 1D NOESY experiment. Irradiation of H-7 at $\delta 5.39$ showed a cross peak to $\mathrm{H}-9$ at $\delta 2.27$.

Partial data for $(\boldsymbol{7 E})-\mathbf{1 2}:{ }^{1} \mathrm{H}$ NMR $5.52(\mathrm{dd}, 1, J=7.3,7.3), 2.32(\mathrm{t}, 2, J=7.3)$.<smiles>[R]OC1C[C@@H](CC(=O)OC)OC1CI</smiles>

$6 \mathrm{R}=\mathrm{H}$ $6 a \mathrm{R}=T B S \longleftarrow$ lutidine, $95 \%$

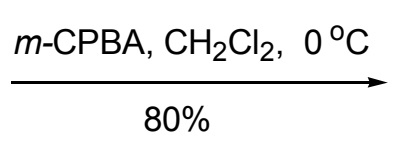

$80 \%$

Methyl cis-2,6-Dioxabicyclo[3.2.0]heptane-3-acetate (15). TBSOTf (0.281 g, $1.065 \mathrm{mmol})$ was added to a solution of alcohol $6^{8}(0.168 \mathrm{~g}, 0.56 \mathrm{mmol})$ and 2,6-lutidine $(0.178 \mathrm{~g}, 1.658 \mathrm{mmol})$ in $\mathrm{CH}_{2} \mathrm{Cl}_{2}(5 \mathrm{~mL})$. The resulting mixture was stirred at room temperature for $12 \mathrm{~h}$ and quenched with $\mathrm{H}_{2} \mathrm{O}(5 \mathrm{~mL})$. The aqueous layer was extracted with EtOAc $(3 \times 5 \mathrm{~mL})$. The combined organic layers were dried over $\mathrm{MgSO}_{4}$ and concentrated. Flash chromatography of the residue on silica gel (25:1 hexanes/EtOAc) gave $0.22 \mathrm{~g}(95 \%)$ of $\mathbf{6 a}:{ }^{1} \mathrm{H}$ NMR 4.67-4.60 (m, 1), 4.48-4.46 (m, 1), 4.22-4.18 (m, 1), 3.69 (s, 3), 3.27 (dd, 1, J = 9.2, 9.2), $3.20(\mathrm{dd}, 1, J=9.2,4.9), 2.63(\mathrm{dd}, 1, J=15.3,6.7), 2.49(\mathrm{dd}, 1, J=15.3,6.1), 2.15(\mathrm{dd}, 1$, $J=13.1,5.5), 1.80(\mathrm{ddd}, 1, J=13.1,10.1,3.7), 0.91(\mathrm{~s}, 9), 0.16(\mathrm{~s}, 3), 0.12(\mathrm{~s}, 3) ;{ }^{13} \mathrm{C} \mathrm{NMR}$ $171.3,83.7,75.1,72.4,51.7,41.7,40.4,25.8$ (3 C) $, 17.9,2.4,-4.4,-4.8$.

$m$-CPBA $(77 \%, 89 \mathrm{mg}, 0.398 \mathrm{mmol})$ was added to a solution of iodide $6 \mathbf{a}(110 \mathrm{mg}$, $0.265 \mathrm{mmol})$ in $\mathrm{CH}_{2} \mathrm{Cl}_{2}(5 \mathrm{~mL})$ at $0{ }^{\circ} \mathrm{C}$ and the mixture was stirred at $0{ }^{\circ} \mathrm{C}$ for $3 \mathrm{~h}$. The reaction was quenched with saturated $\mathrm{Na}_{2} \mathrm{~S}_{2} \mathrm{O}_{3}(5 \mathrm{~mL})$. The aqueous layer was extracted with $\mathrm{CH}_{2} \mathrm{Cl}_{2}$ $(3 \times 5 \mathrm{~mL})$. The combined organic layers were washed with $5 \% \mathrm{NaHCO}_{3}(10 \mathrm{~mL})$ and dried over $\mathrm{MgSO}_{4}$ and concentrated. Flash chromatography of the residue on silica gel $(3: 1$ hexanes/EtOAc) gave $36.5 \mathrm{mg}(80 \%)$ of 15: ${ }^{1} \mathrm{H}$ NMR $5.40(\mathrm{dd}, 1, J=4.3,3.0), 4.95$ (dd, 1 , $J=4.9,3.0,3.0), 4.90-4.84(\mathrm{~m}, 1), 4.74(\mathrm{dd}, 1, J=7.9,4.9), 4.42(\mathrm{dd}, 1, J=7.9,3.0), 3.69$ (s, 3), $2.72(\mathrm{dd}, 1, J=15.9,7.3), 2.66(\mathrm{dd}, 1, J=15.9,6.1), 2.26(\mathrm{dd}, 1, J=13.7,4.6), 1.38(\mathrm{ddd}, 1$, 
$J=13.7,10.3,4.3) ;{ }^{13} \mathrm{C}$ NMR 171.2, 88.6, 77.8, 77.4, 74.6, 51.8, 39.4, 38.9; $\mathrm{MS}\left(\mathrm{DCI} / \mathrm{NH}_{3}\right)$ calculated for $\mathrm{C}_{8} \mathrm{H}_{12} \mathrm{O}_{4}\left(\mathrm{MH}^{+}\right)$173, found 173 .<smiles>C=CC(O)CC1=CC(=O)OC(C)(C)O1</smiles>

13

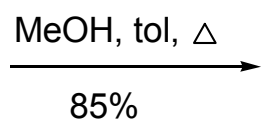

$85 \%$<smiles>C=CC(O)CC(=O)CC(C)=O</smiles>

$13 a$

Methyl (5S)-5-Hydroxy-3-oxo-6-heptenoate (13a). A mixture of allyl alcohol $\mathbf{1 3}{ }^{15,16}$

(7.0 g, $35.3 \mathrm{mmol})$ and $\mathrm{MeOH}(40 \mathrm{~mL}, 98.9 \mathrm{mmoL})$ in toluene $(200 \mathrm{~mL})$ was refluxed for 2 days and concentrated. Flash chromatography of the residue on silica gel (3:1 hexanes/EtOAc) gave $5.16 \mathrm{~g}(85 \%)$ of keto ester 13a: ${ }^{24}{ }^{1} \mathrm{H}$ NMR 5.87 (ddd, $\left.1, J=17.1,11.0,6.1\right), 5.32$ (d, 1, $J=17.1), 5.16(\mathrm{~d}, 1, J=11.0), 4.65-4.58(\mathrm{~m}, 1), 3.75(\mathrm{~s}, 3), 3.52(\mathrm{~s}, 2), 2.82-2.76(\mathrm{~m}, 2) ;{ }^{13} \mathrm{C}$ NMR 202.6, 167.2, 138.6, 115.4, 68.4, 52.4, 49.7, 49.2; IR 3497, 1746, 1714, 1658, 1643; $[\alpha]_{\mathrm{D}}^{20}-23.6\left(\mathrm{c} 0.46, \mathrm{CHCl}_{3}\right)$.

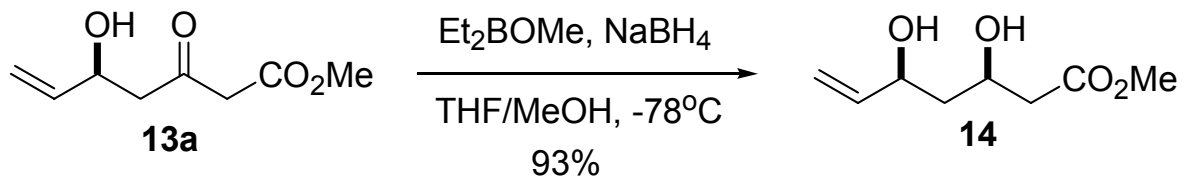

Methyl (3R,5S)-3,5-Dihydroxy-6-heptenoate (14). Et ${ }_{2} \mathrm{BOMe}(5.06 \mathrm{~g}, 50.67 \mathrm{mmol})$ was added to a solution of 13a $(8.3 \mathrm{~g}, 48.26 \mathrm{mmol})$ in $\mathrm{THF}(192 \mathrm{~mL})$ and $\mathrm{MeOH}(48 \mathrm{~mL})$ at $-78^{\circ} \mathrm{C}$. The mixture was stirred at that temperature for $15 \mathrm{~min} . \mathrm{NaBH}_{4}(1.92 \mathrm{~g}, 50.67 \mathrm{mmol})$ was added and the resulting mixture was stirred at $-78^{\circ} \mathrm{C}$ for $4 \mathrm{~h}$, quenched with HOAc $(10 \mathrm{~mL})$, and neutralized with saturated $\mathrm{NaHCO}_{3}(150 \mathrm{~mL})$. The aqueous layer was extracted with $\mathrm{Et}_{2} \mathrm{O}$ $(3 \times 50 \mathrm{~mL})$ and the combined organic layers were dried over $\mathrm{MgSO}_{4}$ and concentrated. The residue was taken up in $\mathrm{MeOH}(250 \mathrm{~mL})$ and most of the $\mathrm{MeOH}$ (ca $200 \mathrm{~mL}$ ) was distilled of to remove the boron-containing byproducts. The residue was concentrated to give $7.8 \mathrm{~g}(93 \%)$ of diol $14^{25}$ that was used without purification. ${ }^{1} \mathrm{H}$ NMR $5.86(\mathrm{ddd}, 1, J=17.1,10.4,6.1), 5.26(\mathrm{~d}$, $1, J=17.1), 5.10(\mathrm{~d}, 1, J=10.4), 4.42-4.36(\mathrm{~m}, 1), 4.34-4.26(\mathrm{~m}, 1), 3.71(\mathrm{~s}, 3), 2.57-2.47(\mathrm{~m}$, 2), 1.72-1.64 (m, 2); ${ }^{13} \mathrm{C}$ NMR 172.6, 140.2, 114.6, 72.5, 68.1, 51.7, 42.2, 41.5; IR 3408, 1736, $1645 ;[\alpha]^{20}-17.8\left(\mathrm{c} 0.73, \mathrm{CHCl}_{3}\right)$. 

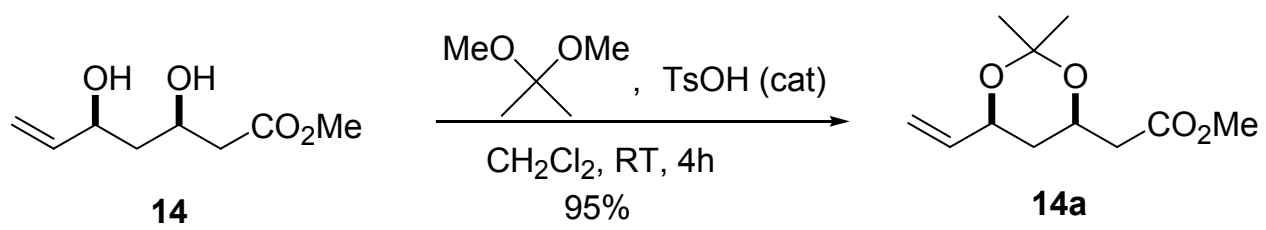

Methyl (4R,6S)-6-Ethenyl-2,2-dimethyl-1,3-dioxane-4-acetate (14a). A mixture of diol 14 (5.5 g, $31.61 \mathrm{mmol})$, 2,2-dimethoxypropane $(32.9 \mathrm{~g}, 0.316 \mathrm{~mol})$ and $\mathrm{TsOH} \cdot \mathrm{H}_{2} \mathrm{O}(0.301 \mathrm{~g}$, $1.58 \mathrm{mmol}$ ) was stirred at room temperature for $4 \mathrm{~h}$. The reaction was quenched with $5 \%$ $\mathrm{NaHCO}_{3}(20 \mathrm{~mL})$ and the aqueous layer was extracted with $\mathrm{Et}_{2} \mathrm{O}(3 \times 20 \mathrm{~mL})$. The combined organic layers were dried over $\mathrm{MgSO}_{4}$ and concentrated to give $6.43 \mathrm{~g}(95 \%)$ of acetonide $\mathbf{1 4 a} \mathbf{a}^{26}$ that was used without purification. ${ }^{1} \mathrm{H}$ NMR 5.82 (ddd, $\left.1, J=17.1,10.4,6.1\right), 5.27$ (d, 1, $J=17.1), 5.13(\mathrm{~d}, 1, J=10.4), 4.41-4.32(\mathrm{~m}, 2), 3.69$ (s, 3), 2.57 (dd, 1, $J=15.3,7.3), 2.41$ (dd, $1, J=15.3,6.1), 1.67(\mathrm{ddd}, 1, J=12.8,2.4,2.4), 1.50(\mathrm{~s}, 3), 1.41(\mathrm{~s}, 3), 1.31(\mathrm{ddd}, 1, J=12.8$, 12.8, 12.8); ${ }^{13} \mathrm{C}$ NMR 171.3, 138.3, 115.5, 98.9, 69.9, 65.6, 51.6, 41.1, 36.2, 30.0, 19.6; IR 1741, $1648 ;[\alpha]_{\mathrm{D}}^{20}-2.8\left(\mathrm{c} 1.43, \mathrm{CHCl}_{3}\right)$.

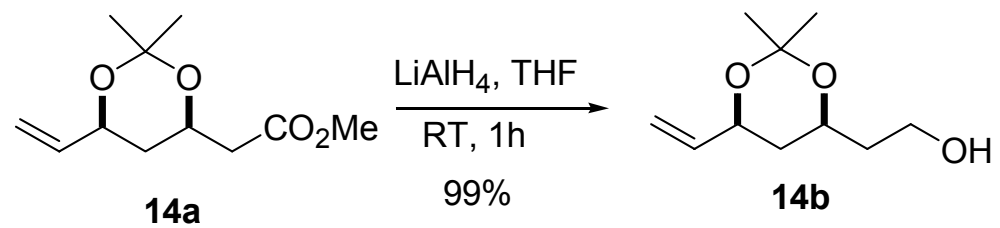

(4S,6S)-6-Ethenyl-2,2-dimethyl-1,3-dioxane-4-ethanol (14b). $\mathrm{LiAlH}_{4}(1.60 \mathrm{~g}$,

$42.06 \mathrm{mmol})$ was added to a solution of ester $14 \mathbf{a}(6.0 \mathrm{~g}, 28.03 \mathrm{mmol})$ in THF $(200 \mathrm{~mL})$ at $0{ }^{\circ} \mathrm{C}$ and the mixture was stirred at room temperature for $1.5 \mathrm{~h}$. The reaction was cooled to $0{ }^{\circ} \mathrm{C}$ and quenched by adding $\mathrm{H}_{2} \mathrm{O}(100 \mathrm{~mL})$ dropwise to the reaction mixture. The aqueous layer was extracted with $\mathrm{Et}_{2} \mathrm{O}(3 \times 50 \mathrm{~mL})$ and the combined organic layers were dried over $\mathrm{MgSO}_{4}$ and concentrated to give $4.95 \mathrm{~g}(95 \%)$ of alcohol 14b: ${ }^{1} \mathrm{H}$ NMR 5.83 (ddd, $\left.1, J=17.1,10.4,6.1\right)$, $5.27(\mathrm{~d}, 1, J=17.1), 5.14(\mathrm{~d}, 1, J=10.4), 4.41-4.36(\mathrm{~m}, 1), 4.20-4.14(\mathrm{~m}, 1), 3.85-3.74(\mathrm{~m}, 2)$, 1.78-1.72 (m, 2), $1.55(\mathrm{ddd}, 1, J=12.8,3.1,3.1), 1.51(\mathrm{~s}, 3), 1.43(\mathrm{~s}, 3), 1.46-1.37(\mathrm{~m}, 1) ;{ }^{13} \mathrm{C}$ NMR 138.4, 115.4, 98.7, 70.0, 68.6, 60.4, 38.0, 36.4, 30.1, 19.7; IR 3415, 1648; $[\alpha]^{20}{ }_{\mathrm{D}}-29.0$ (c $\left.1.73, \mathrm{CHCl}_{3}\right)$. 

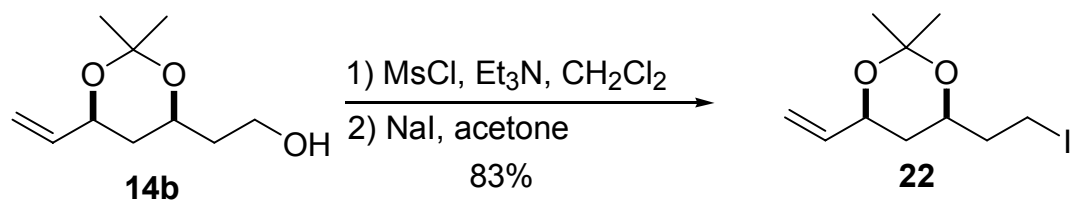

(4R,6S)-6-Ethenyl-4-(2-iodoethyl)-2,2-dimethyl-1,3-dioxane (22). $\mathrm{MsCl}$ (4.53 g,

$39.52 \mathrm{mmol})$ was added to a solution of alcohol $14 \mathrm{~b}(4.90 \mathrm{~g}, 26.34 \mathrm{mmol})$ and $\mathrm{Et}_{3} \mathrm{~N}(4.66 \mathrm{~g}$, $46.10 \mathrm{mmol})$ in $\mathrm{CH}_{2} \mathrm{Cl}_{2}(50 \mathrm{~mL})$ at $0{ }^{\circ} \mathrm{C}$ and the resulting mixture was stirred at room temperature for $15 \mathrm{~min}$. Acetone $(200 \mathrm{~mL}), \mathrm{NaI}(23.64 \mathrm{~g}, 0.158 \mathrm{~mol})$ and $\mathrm{NaHCO}_{3}$ (39.52 mmol) were added and the mixture was heated at $40{ }^{\circ} \mathrm{C}$ in an oil bath for $6 \mathrm{~h}$. The reaction was quenched with saturated $\mathrm{Na}_{2} \mathrm{~S}_{2} \mathrm{O}_{3}(50 \mathrm{~mL})$ and the aqueous layer was extracted with $\mathrm{Et}_{2} \mathrm{O}(3 \times 30 \mathrm{~mL})$. The combined organic layers were dried over $\mathrm{MgSO}_{4}$ and concentrated. Flash chromatography of the residue on silica gel (100:1 hexanes/EtOAc) gave $6.47 \mathrm{~g}(83 \%)$ of iodide 22: ${ }^{1} \mathrm{H}$ NMR $5.82(\mathrm{ddd}, 1, J=17.1,10.4,6.1), 5.27(\mathrm{~d}, 1, J=17.1), 5.14(\mathrm{~d}, 1, J=10.4)$, 4.41-4.37 (m, 1), $4.02(\mathrm{ddd}, 1, J=12.8,6.1,3.7) 3.34-3.24$ (m, 2), 1.99-1.86 (m, 2), 1.54 (ddd, 1, $J=12.8,3.7,2.4), 1.51(\mathrm{~s}, 3), 1.42(\mathrm{~s}, 3), 1.33(\mathrm{ddd}, 1, J=12.8,12.8,12.8) ;{ }^{13} \mathrm{C} \mathrm{NMR} 138.5$, 115.5, 98.8, 70.0, 68.2, 39.4, 36.0, 30.1, 19.8, 2.5; IR 1648; $[\alpha]^{20}{ }_{\mathrm{D}}-43.5$ (c 1.83, $\left.\mathrm{CHCl}_{3}\right)$; HRMS (CI/NH$)$ calculated for $\mathrm{C}_{10} \mathrm{H}_{18} \mathrm{IO}_{2}\left(\mathrm{MH}^{+}\right)$297.0352, found 297.0362.

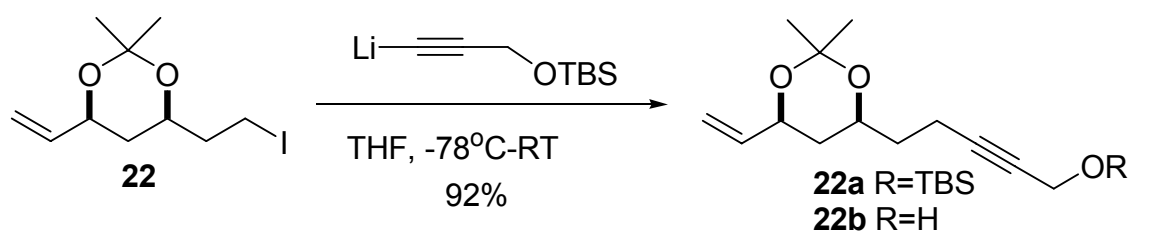

(4S,6S)-6-Ethenyl-2,2-dimethyl-1,3-dioxane-4-pent-2-yn-1-yl t-Butyldimethylsilyl

Ether (22a). $n$-BuLi (1.6 M in hexane, $22 \mathrm{~mL}, 35.12 \mathrm{mmol})$ was added to a solution of tertbutyldimethylsilyl propargyl ether $(5.70 \mathrm{~g}, 33.45 \mathrm{mmol})$ in THF (40 mL) and HMPA (16 mL) at $-78^{\circ} \mathrm{C}$. The resulting mixture was slowly warmed to $-40^{\circ} \mathrm{C}$ over $1 \mathrm{~h}$ and cooled to $-78^{\circ} \mathrm{C}$. A solution of iodide $22(3.96 \mathrm{~g}, 13.38 \mathrm{mmol})$ in THF $(20 \mathrm{~mL})$ was added to the mixture, which was slowly warmed to room temperature. The reaction was quenched with saturated $\mathrm{NH}_{4} \mathrm{Cl}$ and the aqueous layer was extracted with $\mathrm{Et}_{2} \mathrm{O}(3 \times 30 \mathrm{~mL})$. The combined organic layers were dried 
over $\mathrm{MgSO}_{4}$ and concentrated. Flash chromatography of the residue on silica gel (100:1 hexanes/EtOAc) gave $3.17 \mathrm{~g}(70 \%)$ of alkyne $\mathbf{2 2 a}$ followed by $0.60 \mathrm{~g}(22 \%)$ of alcohol $\mathbf{2 2 b}$, which could be readily resilylated to give $\mathbf{2 2 a}$.

A mixture of 22b (0.6 g, $2.67 \mathrm{mmol})$, TBSCl (0.48 g, $3.21 \mathrm{mmol})$ and imidazole $(0.27 \mathrm{~g}$, $4.0 \mathrm{mmol})$ in $\mathrm{CH}_{2} \mathrm{Cl}_{2}(5 \mathrm{~mL})$ was stirred at room temperature for $1 \mathrm{~h}$. The reaction was quenched with $\mathrm{H}_{2} \mathrm{O}(10 \mathrm{~mL})$ and the aqueous layer was extracted with $\mathrm{CH}_{2} \mathrm{Cl}_{2}(3 \times 10 \mathrm{~mL})$. The combined organic layers were dried over $\mathrm{MgSO}_{4}$ and concentrated to give $0.90 \mathrm{~g}(100 \%)$ of 22a: ${ }^{1} \mathrm{H} \mathrm{NMR}$ $5.82(\mathrm{ddd}, 1, J=17.1,10.4,6.1), 5.26(\mathrm{~d}, 1, J=17.1), 5.13(\mathrm{~d}, 1, J=10.4), 4.38-4.33(\mathrm{~m}, 1)$, $4.29(\mathrm{t}, 2, J=2.4), 4.05-3.98(\mathrm{~m}, 1) 2.34-2.30(\mathrm{~m}, 2), 1.73-1.59(\mathrm{~m}, 2), 1.55(\mathrm{ddd}, 1, J=12.8$, 2.4, 2.4), 1.48 (s, 3), 1.41 (s, 3), 1.27 (ddd, $1, J=12.8,12.8,12.8), 0.91(\mathrm{~s}, 9), 0.12(\mathrm{~s}, 6) ;{ }^{13} \mathrm{C}$ NMR 138.7, 115.4, 98.7, 84.6, 78.8, 70.2, 67.2, 51.9, 36.5, 34.9, 30.2, 25.8 (3 C), 19.8, 18.3, 14.5, -5.1 (2 C); IR 2232, 1648; $[\alpha]^{20}{ }_{\mathrm{D}}-21.6$ (c 1.23, $\left.\mathrm{CHCl}_{3}\right)$; HRMS (CI/ $\left.\mathrm{NH}_{3}\right)$ calculated for $\mathrm{C}_{19} \mathrm{H}_{35} \mathrm{O}_{3} \mathrm{Si}\left(\mathrm{MH}^{+}\right)$339.2355, found 339.2362.
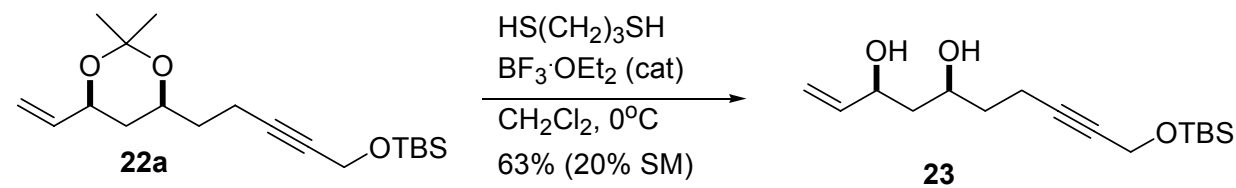

(3S,5S)-10-(t-Butyldimethylsilyloxy)-1-decen-8-yne-3,5-diol (23). $\mathrm{BF}_{3} \cdot \mathrm{OEt}_{2}(81.8 \mathrm{mg}$, $0.576 \mathrm{mmol})$ was added to a mixture of 22a $(2.787 \mathrm{~g}, 8.23 \mathrm{mmol})$ and 1,3-propanedithol (2.317 $\mathrm{g}, 21.41 \mathrm{mmol})$ in $\mathrm{CH}_{2} \mathrm{Cl}_{2}(30 \mathrm{~mL})$ at $0{ }^{\circ} \mathrm{C}$. The mixture was stirred at $0{ }^{\circ} \mathrm{C}$ for $1.5 \mathrm{~h}$ and quenched with $5 \% \mathrm{NaHCO}_{3}(10 \mathrm{~mL})$. The aqueous layer was extracted with $\mathrm{CH}_{2} \mathrm{Cl}_{2}$ $(3 \times 10 \mathrm{~mL})$ and the combined organic layers were dried over $\mathrm{MgSO}_{4}$ and concentrated. Flash chromatography of the residue on silica gel (100:1 to 5:1 hexanes/EtOAc) gave recovered $0.56 \mathrm{~g}$ (20\%) of acetonide $22 \mathrm{a}$, followed by $1.52 \mathrm{~g}(63 \%)$ of diol 23: ${ }^{1} \mathrm{H}$ NMR 5.91 (ddd, 1, $J=17.1$, $10.4,6.1), 5.29(\mathrm{~d}, 1, J=17.1), 5.14(\mathrm{~d}, 1, J=10.4), 4.45-4.39(\mathrm{~m}, 1), 4.33(\mathrm{t}, 2, J=2.4), 4.10-$ 4.03 (m, 1), 3.60 (br s, 1, OH), 3.38 (br s, 1, OH), 2.38 (br t, 2, $J=7.3$ ), 1.76-1.60 (m, 4), 0.94 (s, 9), 0.15 (s, 6); ${ }^{13} \mathrm{C}$ NMR 140.5, 114.5, 84.6, 79.2, 73.6, 71.1, 51.9, 42.6, 36.3, 25.8 (3 C), 
18.3, 14.9, 5.2 (2 C); IR 3358, 2231, 1644; $[\alpha]^{20}{ }_{\mathrm{D}}-6.9\left(\mathrm{c} 0.83, \mathrm{CHCl}_{3}\right) ; \mathrm{HRMS}\left(\mathrm{CI} / \mathrm{NH}_{3}\right)$ calculated for $\mathrm{C}_{16} \mathrm{H}_{31} \mathrm{O}_{3} \mathrm{Si}\left(\mathrm{MH}^{+}\right)$299.2042, found 299.2038.
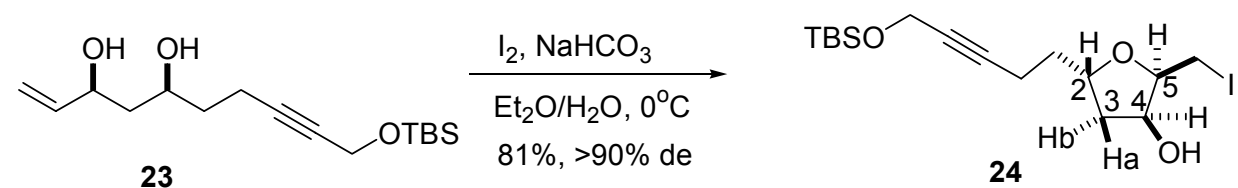

\section{5-[(2S,4S,5R)-Tetrahydro-4-hydroxy-5-iodomethyl-2-furanyl]-2-pentyn-1yl $t$ -}

Butyldimethylsilyl Ether (24). $\mathrm{NaHCO}_{3}(0.97 \mathrm{~g}, 11.52 \mathrm{mmol})$ and $\mathrm{I}_{2}(1.75 \mathrm{~g}, 6.91 \mathrm{mmol})$ were added to a solution of $23(1.72 \mathrm{~g}, 5.76 \mathrm{mmol})$ in $\mathrm{Et}_{2} \mathrm{O}(200 \mathrm{~mL})$ and $\mathrm{H}_{2} \mathrm{O}(80 \mathrm{~mL})$ at $0{ }^{\circ} \mathrm{C}$. The mixture was stirred at $0{ }^{\circ} \mathrm{C}$ for $4 \mathrm{~h}$ and quenched with saturated $\mathrm{Na}_{2} \mathrm{~S}_{2} \mathrm{O}_{3}(50 \mathrm{~mL})$. The aqueous layer was extracted with $\mathrm{Et}_{2} \mathrm{O}(3 \times 50 \mathrm{~mL})$ and the combined organic layers were dried over $\mathrm{MgSO}_{4}$ and concentrated. Flash chromatography of the residue on silica gel (9:1 hexanes/EtOAc) gave $1.98 \mathrm{~g}(81 \%)$ of iodide (5R)-24, followed by $0.10 \mathrm{~g}(4 \%)$ of diastereomer (5S)-24. The stereochemistry of (5R)-24 was established by 1D NOESY studies. Irradiation of $\mathrm{H}-5$ at $\delta 4.17$ showed a cross peak to $\mathrm{H}-4$ at $\delta 4.55$, but not to $\mathrm{H}-2$ at $\delta 4.40$. Irradiation of $\mathrm{H}-4$ at $\delta 4.55$ showed cross peaks to $\mathrm{H}-5$ at $\delta 4.17$ and to $\mathrm{H}-3 \mathrm{~b}$ at $\delta 1.81$. Irradiation of $\mathrm{H}-2$ at $\delta 4.40$ showed a cross peak to H-3a at $\delta 2.18$, but not to H-5 at $\delta 4.17$ and $\mathrm{H}-4$ at $\delta 4.55$.

Data for (5R)-24: ${ }^{1} \mathrm{H}$ NMR $4.55(\mathrm{ddd}, 1, J=3.7,3.7,3.7), 4.44-4.37$ (m, 1), 4.29 (t, 2 , $J=2.4), 4.17(\mathrm{ddd}, 1, J=9.7,6.1,3.7), 3.29-3.21(\mathrm{~m}, 2), 2.34-2.28(\mathrm{~m}, 2), 2.18(\mathrm{dd}, 1, J=13.4$, 5.5), 1.82-1.63 (m, 3), $0.91(\mathrm{~s}, 9), 0.11(\mathrm{~s}, 6) ;{ }^{13} \mathrm{C}$ NMR 84.4, 82.1, 79.0, 78.0, 72.7, 51.9, 41.2, 34.9, 25.8 (3 C), 18.3, 15.6, 2.0, -5.1 (2 C); IR 3442, 2231; $[\alpha]^{20}{ }_{\mathrm{D}}+29.7$ (c 1.60, $\mathrm{CHCl}_{3}$ ); $\mathrm{HRMS}$ $\left(\mathrm{CI} / \mathrm{NH}_{3}\right)$ calculated for $\mathrm{C}_{16} \mathrm{H}_{33} \mathrm{INO}_{3} \mathrm{Si}\left(\mathrm{MNH}_{4}{ }^{+}\right)$442.1275, found 442.1284.

Data for (5S)-24: ${ }^{1} \mathrm{H}$ NMR 4.32-4.25 (m, 2), $4.29(\mathrm{t}, 2, J=2.4), 3.84-3.80(\mathrm{~m}, 1), 3.27$ $(\mathrm{dd}, 1, J=10.4,4.3), 3.12(\mathrm{dd}, 1, J=10.4,7.3), 2.33(\mathrm{dt}, 2, J=7.3,2.4), 2.00(\mathrm{ddd}, 1, J=13.4$, 5.5, 2.4), 1.87-1.71 (m, 3), 0.91 (s, 9), 0.12 (s, 6); ${ }^{13} \mathrm{C}$ NMR 85.6, 84.4, 79.0, 77.9, 76.7, 51.9, 40.4, 34.5, 25.8 (3 C), 18.3, 15.6, 7.4, -5.1 (2 C). 


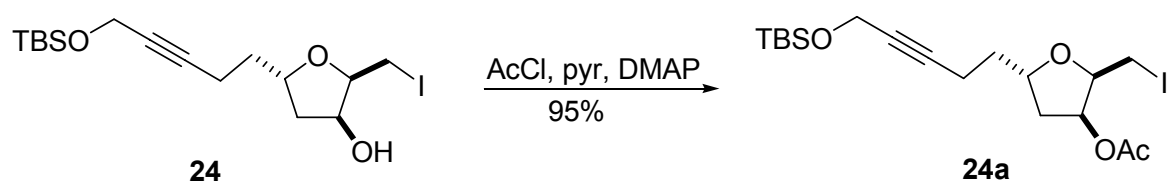

\section{5-[(2S,4S,5R)-4-Acetoxy-tetrahydro-5-iodomethyl-2-furanyl]-2-pentyn-1yl $t$ -}

Butyldimethylsilyl Ether (24). $\mathrm{AcCl}(0.208 \mathrm{~g}, 2.651 \mathrm{mmol})$ was added to a mixture of iodide 24 (0.450 g, $1.060 \mathrm{mmol})$, pyridine $(0.210 \mathrm{~g}, 2.651 \mathrm{mmol})$ and DMAP $(6.5 \mathrm{mg}, 0.053 \mathrm{mmol})$ in $\mathrm{CH}_{2} \mathrm{Cl}_{2}(5 \mathrm{~mL})$. The resulting mixture was stirred at room temperature for $2 \mathrm{~h}$ and the reaction was quenched with $\mathrm{H}_{2} \mathrm{O}(10 \mathrm{~mL})$. The aqueous layer was extracted with $\mathrm{CH}_{2} \mathrm{Cl}_{2}(3 \times 10 \mathrm{~mL})$ and the combined organic layers were dried over $\mathrm{MgSO}_{4}$ and concentrated. Flash chromatography of the residue on silica gel (25:1 hexanes/EtOAc) gave $0.470 \mathrm{~g}(95 \%)$ of acetate 24a: ${ }^{1} \mathrm{H}$ NMR $5.46(\mathrm{dd}, 1, J=3.7,3.7), 4.35-4.26(\mathrm{~m}, 2), 4.29(\mathrm{t}, 2, J=2.4), 3.21(\mathrm{~d}, 2$, $J=7.9), 2.34-2.30(\mathrm{~m}, 2), 2.21(\mathrm{dd}, 1, J=14.0,5.5), 2.11(\mathrm{~s}, 3), 1.88(\mathrm{ddd}, 1, J=14.0,9.5,3.7)$, 1.82-1.63 (m, 2), 0.91 (s, 9), 0.11 (s, 6); ${ }^{13} \mathrm{C}$ NMR 170.1, 84.2, 80.6, 79.1, 77.8, 74.8, 51.9, 39.3, 34.7, 25.8 (3 C), 20.9, 18.3, 15.6, 0.7, -5.1 (2 C); IR 2232, 1743; $[\alpha]^{20}{ }_{\mathrm{D}}+39.0\left(\mathrm{c} 1.23, \mathrm{CHCl}_{3}\right)$; HRMS $\left(\mathrm{CI} / \mathrm{NH}_{3}\right)$ calculated for $\mathrm{C}_{18} \mathrm{H}_{35} \mathrm{INO}_{4} \mathrm{Si}\left(\mathrm{MNH}_{4}{ }^{+}\right)$484.1380, found 484.1365.

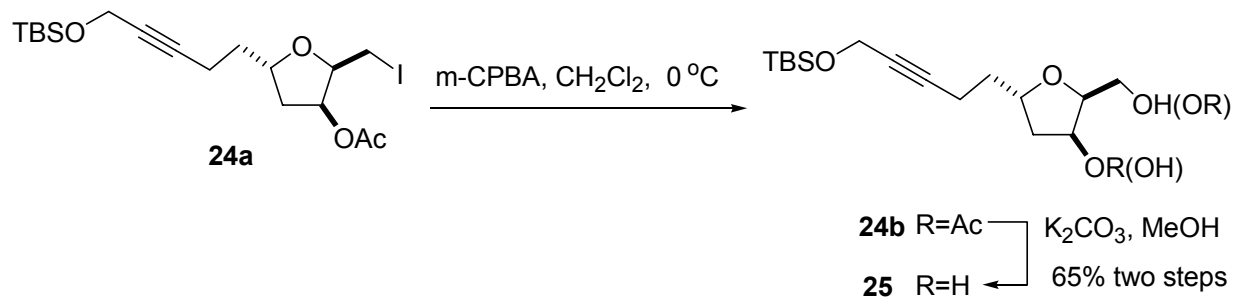

\section{5-[(2S,4S,5S)-Tetrahydro-4-hydroxy-5-hydroxymethyl-2-furanyl]-2-pentyn-1yl $t$ -}

Butyldimethylsilyl Ether (25). $m$-CPBA (77\%, $0.389 \mathrm{~g}, 1.738 \mathrm{mmol})$ was added to a solution of iodide 24a $(0.405 \mathrm{~g}, 0.869 \mathrm{mmol})$ in $\mathrm{CH}_{2} \mathrm{Cl}_{2}(20 \mathrm{~mL})$ at $0{ }^{\circ} \mathrm{C}$ and the mixture was stirred at $0{ }^{\circ} \mathrm{C}$ for $3 \mathrm{~h}$. The reaction was quenched with saturated $\mathrm{Na}_{2} \mathrm{~S}_{2} \mathrm{O}_{3}(10 \mathrm{~mL})$. The aqueous layer was extracted with $\mathrm{CH}_{2} \mathrm{Cl}_{2}(3 \times 10 \mathrm{~mL})$ and the combined organic layers were washed with $5 \%$ $\mathrm{NaHCO}_{3}(30 \mathrm{~mL})$ and dried over $\mathrm{MgSO}_{4}$ and concentrated to give $0.398 \mathrm{~g}$ of a 1:1 mixture of acetoxy alcohols $\mathbf{2 4 b}$. 
A solution of crude $\mathbf{2 4 b}(0.398 \mathrm{~g}, 1.116 \mathrm{mmol})$ and $\mathrm{K}_{2} \mathrm{CO}_{3}(0.154 \mathrm{~g}, 1.116 \mathrm{mmol})$ in $\mathrm{MeOH}(2 \mathrm{~mL})$ was stirred at room temperature for $30 \mathrm{~min}$. The solvent was evaporated and the residue was diluted with EtOAc $(10 \mathrm{~mL})$. The organic layer was washed with saturated $\mathrm{NH}_{4} \mathrm{Cl}$ $(10 \mathrm{~mL})$, dried over $\mathrm{MgSO}_{4}$ and concentrated. Flash chromatography of the residue on silica gel (1:1 hexanes/EtOAc) gave $0.118 \mathrm{~g}(65 \%)$ of diol 25: ${ }^{1} \mathrm{H}$ NMR 4.53 (br s, 1), 4.42-4.34 (m, 1), $4.29(\mathrm{t}, 2, J=2.4), 3.97-3.92$ (m, 3), 3.50-2.95 (br s, 2, OH), 2.36-2.31 (m, 2), 2.13 (dd, 1, $J=14.7,6.5), 1.83-1.65(\mathrm{~m}, 3), 0.91(\mathrm{~s}, 9), 0.12(\mathrm{~s}, 6) ;{ }^{13} \mathrm{C} \mathrm{NMR} 84.5,80.3,78.9,77.1,74.3$, 61.8, 51.9, 41.9, 34.7, 25.8 (3 C), 18.3, 15.7, -5.2 (2 C); IR 3404, 2232; [ $\alpha]^{20}{ }_{\mathrm{D}}-3.8$ (c 0.58, $\left.\mathrm{CHCl}_{3}\right)$; HRMS (CI/NH$)$ calculated for $\mathrm{C}_{16} \mathrm{H}_{34} \mathrm{NO}_{4} \mathrm{Si}\left(\mathrm{MNH}_{4}{ }^{+}\right)$332.2257, found 332.2262.

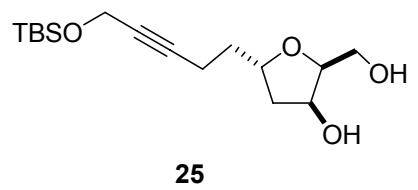

25

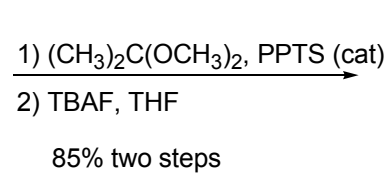

$85 \%$ two steps

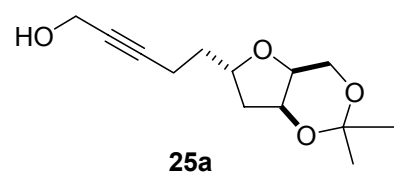

25a

Acetonide 25a. A mixture of diol 25 (0.64 g, $2.04 \mathrm{mmol}), 2$,2-dimethoxypropane (4.2 g, $40.7 \mathrm{mmol})$ and PPTS (25.6 mg, $0.102 \mathrm{mmol})$ was stirred at room temperature overnight. The reaction was diluted with $\mathrm{CH}_{2} \mathrm{Cl}_{2}(20 \mathrm{~mL})$ and quenched with $5 \% \mathrm{NaHCO}_{3}(15 \mathrm{~mL})$. The aqueous layer was extracted with $\mathrm{CH}_{2} \mathrm{Cl}_{2}(3 \times 15 \mathrm{~mL})$. The combined organic layers were dried over $\mathrm{MgSO}_{4}$ and concentrated to give $0.70 \mathrm{~g}$ of crude dioxane.

TBAF (1.0 M in THF, $2 \mathrm{~mL}, 2 \mathrm{mmol}$ ) was added to a solution of the above crude dioxane in THF $(10 \mathrm{~mL})$ at $0{ }^{\circ} \mathrm{C}$. The mixture was stirred at $0{ }^{\circ} \mathrm{C}$ for $30 \mathrm{~min}$ and quenched with saturated $\mathrm{NH}_{4} \mathrm{Cl}(10 \mathrm{~mL})$. The aqueous layer was extracted with $\mathrm{Et}_{2} \mathrm{O}(3 \times 10 \mathrm{~mL})$ and the combined organic layers were dried over $\mathrm{MgSO}_{4}$ and concentrated. Flash chromatography of the residue on silica gel (3:1 hexanes/EtOAc) gave $0.417 \mathrm{~g}(85 \%)$ of alcohol 25a: ${ }^{1} \mathrm{H}$ NMR 4.43(dd, 1 , $J=3.7,3.1), 4.44-4.36(\mathrm{~m}, 1), 4.26($ br s, 2$), 4.01$ (dd, $1, J=12.8,3.7), 3.89$ (dd, $1, J=12.8$, 2.4), 3.83 (ddd, $1, J=3.7,3.1,2.4), 2.41-2.28(\mathrm{~m}, 2), 2.15(\mathrm{dd}, 1, J=13.4,5.5), 1.84-1.65$ (m, 3), 1.44 (s, 3), 1.39 (s, 3); ${ }^{13} \mathrm{C}$ NMR 97.6, 85.7, 78.6, 77.5, 73.7, 71.1, 60.8, 51.2, 39.9, 34.9, 28.2, 19.8, 15.7; IR 3440, 2222; $[\alpha]^{20}{ }_{\mathrm{D}}-1.5\left(\mathrm{c} 0.85, \mathrm{CHCl}_{3}\right)$; HRMS $\left(\mathrm{CI} / \mathrm{NH}_{3}\right)$ calculated for $\mathrm{C}_{13} \mathrm{H}_{24} \mathrm{NO}_{4}\left(\mathrm{MNH}_{4}^{+}\right)$258.1705, found 258.1704. 


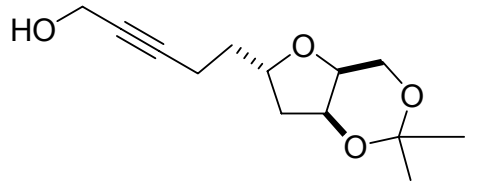

$25 a$

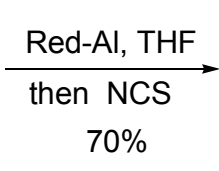

Chloroalkenol 25b. Red-Al (3.3 $\mathrm{M}$ in toluene, $0.45 \mathrm{~mL}, 1.50 \mathrm{mmol})$ was added to a solution of $25 \mathrm{a}(180 \mathrm{mg}, 0.748 \mathrm{mmol})$ in THF $(3 \mathrm{~mL})$. The mixture was stirred at room temperature for $8 \mathrm{~h}$ and cooled to $-78^{\circ} \mathrm{C}$. A solution of $N$-chlorosuccinimide $(0.50 \mathrm{~g}$, $3.74 \mathrm{mmol})$ in THF $(10 \mathrm{~mL})$ was added and the resulting mixture was slowly warmed to room temperature overnight. The reaction was quenched with saturated $\mathrm{NH}_{4} \mathrm{Cl}(10 \mathrm{~mL})$ and the aqueous layer was extracted with $\mathrm{Et}_{2} \mathrm{O}(3 \times 10 \mathrm{~mL})$. The combined organic layers were dried over $\mathrm{MgSO}_{4}$ and concentrated. Flash chromatography of the residue on silica gel $(2: 1$ hexanes/EtOAc) gave $145 \mathrm{mg}(70 \%)$ of allylic alcohol 25b: ${ }^{1} \mathrm{H}$ NMR 5.78 (t, 1, $\left.J=6.7\right), 4.43$ $(\mathrm{dd}, 1, J=3.7,3.7), 4.37-4.29(\mathrm{~m}, 1), 4.29(\mathrm{~d}, 2, J=6.7), 4.01(\mathrm{dd}, 1, J=12.8,3.7), 3.88(\mathrm{dd}, 1$, $J=12.8,3.1), 3.87-3.84(\mathrm{~m}, 1), 2.57-2.37(\mathrm{~m}, 2), 2.13(\mathrm{dd}, 1, J=13.4,5.5), 1.84-1.78(\mathrm{~m}, 2)$, 1.72-1.60 (m, 1), 1.44 (s, 3), 1.39 (s, 3); ${ }^{13} \mathrm{C}$ NMR 136.5, 124.8, 97.6, 77.6, 73.7, 71.1, 60.8,

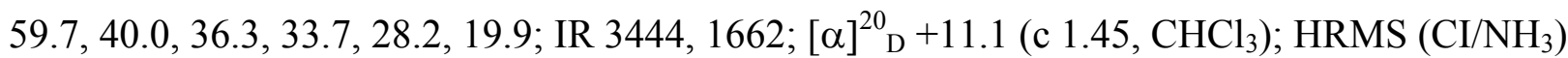
calculated for $\mathrm{C}_{13} \mathrm{H}_{22} \mathrm{O}_{4} \mathrm{Cl}\left(\mathrm{MH}^{+}\right)$277.1207, found 277.1201.
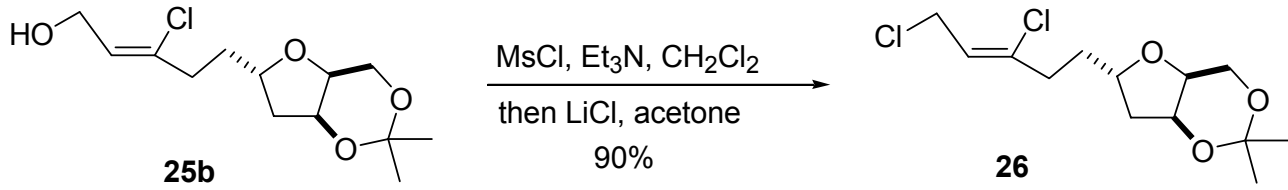

Dichloride 26. $\mathrm{Et}_{3} \mathrm{~N}(95 \mathrm{mg}, 0.939 \mathrm{mmol})$ and $\mathrm{MsCl}(107.5 \mathrm{mg}, 0.939 \mathrm{mmol})$ were added to a solution of alcohol $\mathbf{2 5 b}(130 \mathrm{mg}, 0.469 \mathrm{mmol})$ in $\mathrm{CH}_{2} \mathrm{Cl}_{2}(3 \mathrm{~mL})$. The mixture was stirred at room temperature for $20 \mathrm{~min}$. Acetone $(12 \mathrm{~mL})$ and $\mathrm{LiCl}(199 \mathrm{mg}, 4.69 \mathrm{mmol})$ were added and the mixture was stirred at room temperature overnight. The reaction was quenched with $\mathrm{H}_{2} \mathrm{O}(5 \mathrm{~mL})$. The aqueous layer was extracted with $\mathrm{CH}_{2} \mathrm{Cl}_{2}(3 \times 10 \mathrm{~mL})$ and the combined organic layers were dried over $\mathrm{MgSO}_{4}$ and concentrated. Flash chromatography of the residue on silica gel (25:1 hexanes/EtOAc) gave $124.6 \mathrm{mg}(90 \%)$ of chloride $26:{ }^{1} \mathrm{H}$ NMR 5.78 (t, 1 , $J=7.3), 4.43(\mathrm{dd}, 1, J=3.1,3.1), 4.35-4.28(\mathrm{~m}, 1), 4.19(\mathrm{~d}, 2, J=7.3), 4.01(\mathrm{dd}, 1, J=12.2$, 
3.1), 3.88-3.84 (m, 1), $3.87(\mathrm{dd}, 1, J=12.2,3.1), 2.61-2.40(\mathrm{~m}, 2), 2.12(\mathrm{dd}, 1, J=13.4,5.5)$, 1.86-1.78 (m, 2), $1.68(\mathrm{ddd}, 1, J=13.4,9.8,3.7), 1.43(\mathrm{~s}, 3), 1.39(\mathrm{~s}, 3) ;{ }^{13} \mathrm{C}$ NMR 139.6, 121.5, 97.6, 77.5, 73.8, 71.1, 60.8, 40.2, 40.0, 36.3, 33.6, 28.1, 19.9; IR 1654; $[\alpha]^{20}+8.6$ (c 0.86 , $\left.\mathrm{CHCl}_{3}\right)$; HRMS (CI/NH$)$ calculated for $\mathrm{C}_{13} \mathrm{H}_{24} \mathrm{NO}_{3} \mathrm{Cl}_{2}\left(\mathrm{MNH}_{4}{ }^{+}\right)$312.1133, found 312.1128.

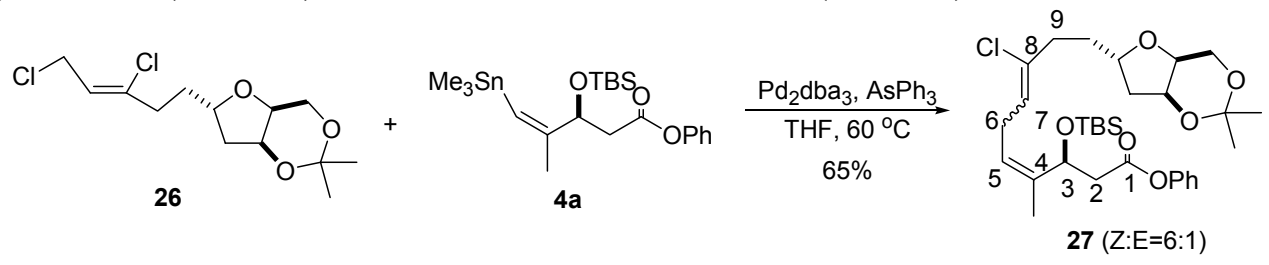

Stille Product 27. $\mathrm{AsPh}_{3}(29 \mathrm{mg}, 0.0948 \mathrm{mmol})$ and $\mathrm{Pd}_{2} \mathrm{dba}_{3}(21.7 \mathrm{mg}, 0.0237 \mathrm{mmol})$ were added to a solution of allylic chloride 26 (70 $\mathrm{mg}, 0.237 \mathrm{mmol})$ in THF (3 mL). The mixture was stirred at room temperature for $10 \mathrm{~min}$ and a solution of vinyltin $4 \mathbf{a}(137 \mathrm{mg}$, $0.285 \mathrm{mmol})$ in THF $(1 \mathrm{~mL})$ was added. The reaction mixture was heated to $60{ }^{\circ} \mathrm{C}$ for $18 \mathrm{~h}$ and concentrated. Flash chromatography of the residue on silica gel (25:1 hexanes/EtOAc) gave $15 \mathrm{mg}(10 \%)$ a $2: 1$ mixture of (7E)- and (7Z)-27 followed by $89 \mathrm{mg}(65 \%)$ of (7Z)-27: The stereochemistry of (7Z)-27 was established by a 1D NOESY study. Irradiation of H-7 at $\delta 5.45$ showed a cross peak to H-9 at $\delta$ 2.52-2.31.

Data for (7Z) -27: ${ }^{1} \mathrm{H}$ NMR $7.37(\mathrm{dd}, 2, J=7.9,7.3), 7.22(\mathrm{t}, 1, J=7.3), 7.08$ (d, 2, $J=7.9), 5.45(\mathrm{dd}, 1, J=7.3,6.7), 5.21-5.16(\mathrm{~m}, 2), 4.42(\mathrm{dd}, 1, J=3.7,3.1), 4.33-4.26(\mathrm{~m}, 1)$, $3.99(\mathrm{dd}, 1, J=12.8,3.7), 3.87(\mathrm{dd}, 1, J=12.8,3.1), 3.87-3.84(\mathrm{~m}, 1), 3.07-2.90(\mathrm{~m}, 2), 2.89$ (dd, $1, J=14.7,8.5), 2.58(\mathrm{dd}, 1, J=14.7,4.9), 2.52-2.31(\mathrm{~m}, 2), 2.10(\mathrm{dd}, 1, J=13.4,5.5)$, 1.80-1.75 (m, 2), 1.75 (s, 3), $1.66(\mathrm{ddd}, 1, J=13.4,9.8,3.7), 1.43$ (s, 3), 1.39 (s, 3), $0.88(\mathrm{~s}, 9)$, 0.08 (s, 3), 0.04 (s, 3); ${ }^{13} \mathrm{C}$ NMR 169.4, 150.7, 137.6, 134.7, 129.3 (2 C), , 125.7, 123.4, 123.1, 121.5 (2 C), 97.6, 77.7, 73.8, 71.2, 67.1, 60.9, 41.9, 40.0, 36.3, 33.9, 28.1, 27.2, 25.7 (3 C), 20.0, 18.0, 17.5, -4.9, -5.1; IR 1760, 1593; $[\alpha]^{20}{ }_{\mathrm{D}}+6.2\left(\mathrm{c} 1.6, \mathrm{CHCl}_{3}\right)$.

Partial Data for (7E)-27: ${ }^{1} \mathrm{H}$ NMR $5.53(\mathrm{dd}, 1, J=7.3,7.3), 4.39$ (dd, 1, $\left.J=3.7,3.1\right)$. 


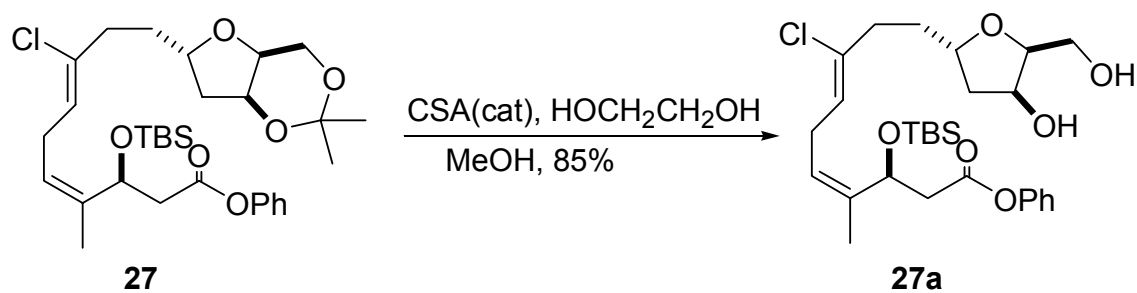

Phenyl (3S,4Z,7Z)-3-(t-Butyldimethylsilyloxy)-8-chloro-4-methyl-10-[(2S,4S,5S)tetrahydro-4-hydroxy-5-(hydroxymethyl)-2-furanyl]-4,7-decadienoate (27a). CSA (2.3 mg, $0.01 \mathrm{mmol})$ was added to a solution of $27(82 \mathrm{mg}, 0.142 \mathrm{mmol})$ and ethylene glycol (439 $\mathrm{mg}$, $7.08 \mathrm{mmol})$ in $\mathrm{MeOH}(2 \mathrm{~mL})$. The mixture was stirred to room temperature for $2 \mathrm{~h}$. The reaction was quenched with $\mathrm{H}_{2} \mathrm{O}(2 \mathrm{~mL})$. The aqueous layer was extracted with ethyl acetate $(3 \times 5 \mathrm{~mL})$ and the combined organic layers were dried over $\mathrm{MgSO}_{4}$ and concentrated. Flash chromatography of the residue on silica gel (3:1 to 1:1 hexanes/EtOAc) gave $65 \mathrm{mg}(85 \%)$ of diol 27a: ${ }^{1} \mathrm{H}$ NMR $7.37(\mathrm{dd}, 2, J=8.4,7.3), 7.22(\mathrm{t}, 1, J=7.3), 7.08(\mathrm{~d}, 2, J=8.4), 5.44(\mathrm{dd}, 1$, $J=7.3,6.7), 5.22-5.15(\mathrm{~m}, 2), 4.51$ (br s, 1), 4.28-4.21 (m, 1), 3.96-3.90 (m, 3), 3.24 (dd, 1 , $J=12.8,3.7, \mathrm{OH}), 3.07-2.92(\mathrm{~m}, 2), 2.89(\mathrm{dd}, 1, J=14.7,8.5), 2.59(\mathrm{ddd}, 1, J=14.7,4.9,1.2)$, 2.50-2.32 (m, 2), $2.07(\mathrm{ddd}, 1, J=13.4,3.7,3.7), 1.80-1.69(\mathrm{~m}, 3), 1.76(\mathrm{~s}, 3), 0.89(\mathrm{~s}, 9), 0.09$ (s, 3), 0.04 (s, 3); ${ }^{13} \mathrm{C}$ NMR 169.5, 150.7, 137.6, 134.5, 129.4 (2 C), 125.7, 123.6, 123.1, 121.5 (2 C), 80.2, 77.3, 74.4, 67.1, 61.9, 42.1, 41.9, 36.1, 33.7, 27.2, 25.7 (3 C), 18.0, 17.5, -4.9, -5.1; IR 3406, 1760, 1658, 1594; $[\alpha]^{20}{ }_{\mathrm{D}}+5.5\left(\mathrm{c} 1.0, \mathrm{CHCl}_{3}\right)$; HRMS (MALDI) calculated for $\mathrm{C}_{28} \mathrm{H}_{43} \mathrm{O}_{6} \mathrm{NaSiCl}\left(\mathrm{MNa}^{+}\right)$561.2410, found 561.2447.

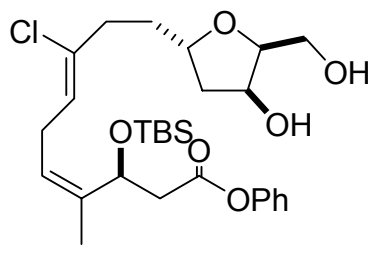

$27 a$

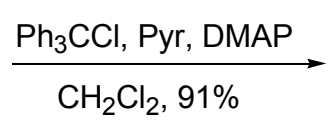

Phenyl (3S,4Z,7Z)-3-(t-Butyldimethylsilyloxy)-8-chloro-4-methyl-10-[(2S,4S,5S)tetrahydro-4-hydroxy-5-(triphenylmethoxymethyl)-2-furanyl]-4,7-decadienoate (27b). A mixture of diol 27a (56 mg, $0.104 \mathrm{mmol})$, triphenylmethyl chloride (37.7 mg, $0.135 \mathrm{mmol}$ ), pyridine (21.4 mg, $0.27 \mathrm{mmol}$ ), and DMAP (1.3 mg, $0.0104 \mathrm{mmol})$ in $\mathrm{CH}_{2} \mathrm{Cl}_{2}(3 \mathrm{~mL})$ was stirred 
at room temperature for $12 \mathrm{~h}$. The solvent was evaporated and flash chromatography of the residue on silica gel (9:1 hexanes/EtOAc) gave $74 \mathrm{mg}(91 \%)$ of $\mathbf{2 7 b}:{ }^{1} \mathrm{H}$ NMR 7.45-7.06 (m, 20), $5.43(\mathrm{dd}, 1, J=7.3,6.7), 5.18-5.14(\mathrm{~m}, 2), 4.54(\mathrm{ddd}, 1, J=3.7,3.7,3.7), 4.25-4.18(\mathrm{~m}, 1)$, 4.16-4.12 (m, 1), $3.45(\mathrm{dd}, 1, J=9.7,4.9), 3.29(\mathrm{dd}, 1, J=9.7,7.3), 3.04-2.89$ (m, 2), 2.87 (dd, $1, J=14.7,9.2), 2.61(\mathrm{~d}, 1, J=3.1, \mathrm{OH}), 2.57(\mathrm{dd}, 1, J=14.7,4.3), 2.50-2.30(\mathrm{~m}, 2), 2.09$ (dd, $1, J=13.4,5.5), 1.78-1.66(\mathrm{~m}, 3), 1.73(\mathrm{~s}, 3), 0.88(\mathrm{~s}, 9), 0.07(\mathrm{~s}, 3), 0.02(\mathrm{~s}, 3) ;{ }^{13} \mathrm{C}$ NMR 169.4, 150.7, 143.5 (3 C), 137.6, 134.7, 129.3 (2 C), 128.4 (6 C), 128.0 (6 C), 127.2 (3 C), 125.7, 123.7, 123.2, 121.5 (2 C), 87.2, 80.1, 77.3, 73.6, 67.1, 62.6, 41.9, 41.2, 36.2, 33.8, 27.2, 25.7 (3 C), 18.0, 17.5, -4.9, -5.1; IR 3460, 1750, 1652; $[\alpha]^{20}{ }_{\mathrm{D}}+5.8\left(\mathrm{c} 0.31, \mathrm{CHCl}_{3}\right) ; \mathrm{HRMS}$ (MALDI) calculated for $\mathrm{C}_{47} \mathrm{H}_{57} \mathrm{O}_{6} \mathrm{NaSiCl}\left(\mathrm{MNa}^{+}\right)$803.3505, found 803.3537.

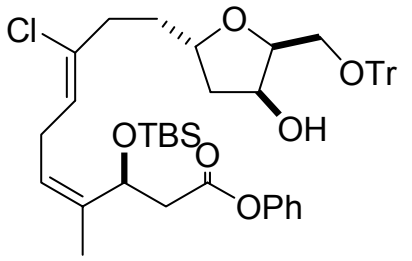

27b

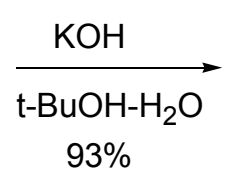

(3S,4Z,7Z)-3-(t-Butyldimethylsilyloxy)-8-chloro-4-methyl-10-[(2S,4S,5S)-tetrahydro-

\section{4-hydroxy-5-(triphenylmethoxymethyl)-2-furanyl]-4,7-decadienoic Acid (28). KOH}

(0.95 mL, $0.5 \mathrm{M}$ in $\mathrm{H}_{2} \mathrm{O}, 0.474 \mathrm{mmol}$ ) was added to a solution of phenyl ester $27 \mathbf{b}$ (74 $\mathrm{mg}$, $0.0947 \mathrm{mmol})$ in $t$-BuOH $(4 \mathrm{~mL})$. The mixture was stirred at room temperature for $6 \mathrm{~h}$. The reaction was quenched with saturated $\mathrm{NaH}_{2} \mathrm{PO}_{4}(5 \mathrm{~mL})$. The aqueous layer was extracted with EtOAc $(3 \times 10 \mathrm{~mL})$ and the combined organic layers were dried over $\mathrm{MgSO}_{4}$ and concentrated. Flash chromatography of the residue on silica gel (3:1 to 1:1 hexanes/EtOAc) gave $62 \mathrm{mg}(93 \%)$ of acid 28: ${ }^{1} \mathrm{H}$ NMR 7.45-7.22 (m, 15), $5.50(\mathrm{t}, 1, J=7.3), 5.29(\mathrm{t}, 1, J=7.9), 4.98(\mathrm{dd}, 1$, $J=7.4,6.7), 4.43(\mathrm{dd}, 1, J=3.7,3.7), 4.24-4.17(\mathrm{~m}, 1), 4.09-4.05$ (m, 1), 3.47-3.27 (m, 2), 2.88 $(\mathrm{dd}, 2, J=7.9,7.3), 2.58(\mathrm{dd}, 1, J=13.4,6.7), 2.52-2.35(\mathrm{~m}, 2), 2.44(\mathrm{dd}, 1, J=13.4,7.4), 2.15$ $(\mathrm{dd}, 1, J=13.4,6.1), 1.77-1.71(\mathrm{~m}, 3), 1.69(\mathrm{~s}, 3), 0.88(\mathrm{~s}, 9), 0.08(\mathrm{~s}, 3), 0.03(\mathrm{~s}, 3) ;{ }^{13} \mathrm{C}$ NMR 174.8, 143.5 (3 C), 137.2, 133.8, 128.5 (6 C), 127.9 (6 C), 127.2 (3 C), 124.3, 123.1, 87.1, 80.5, 
76.3, 73.4, 67.0, 62.3, 41.7, 41.1, 36.0, 33.2, 26.8, 25.6 (3 C), 18.0, 17.2, -4.9, -5.2; IR 3459, 1712,$1560 ;[\alpha]^{20}{ }_{\mathrm{D}}+28.9\left(\mathrm{c} 0.58, \mathrm{CHCl}_{3}\right)$.

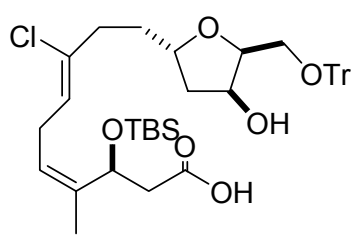

28

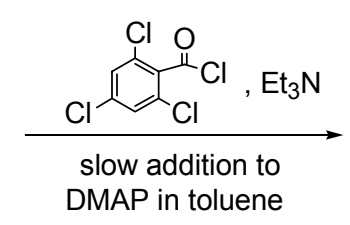

DMAP in toluene

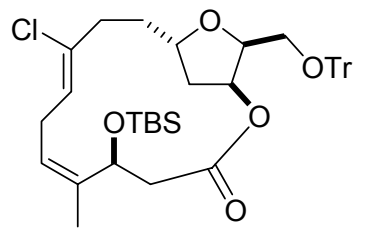

$29(65 \%)+15 \%$ dimer $29 a$

$(1 S, 5 S, 6 Z, 9 Z, 13 S, 15 S)-5-(t$-Butyldimethylsilyloxy)-10-chloro-15-

[(triphenylmethoxy)methyl]-6-methyl-2,14-Dioxabicyclo[11.2.1]hexadeca-6,9-dien-3-one

(29). $\mathrm{Et}_{3} \mathrm{~N}$ (31 mg, $0.307 \mathrm{mmol}$ ) and 2,4,6-trichlorobenzoyl chloride (62.3 mg, $0.256 \mathrm{mmol}$ ) were added to a solution of acid $28(18 \mathrm{mg}, 0.0256 \mathrm{mmol})$ in THF $(1 \mathrm{~mL})$. The mixture was stirred at room temperature for $2 \mathrm{~h}$ and diluted with toluene $(9 \mathrm{~mL})$. The resulting mixture was added slowly to a solution of DMAP $(78 \mathrm{mg}, 0.64 \mathrm{mmol})$ in toluene $(80 \mathrm{~mL})$ through a syringe pump over $15 \mathrm{~h}$. After stirring for additional $2 \mathrm{~h}$ at room temperature, the reaction was quenched with saturated $\mathrm{NH}_{4} \mathrm{Cl}(10 \mathrm{~mL})$. The organic layer was separated and aqueous layer was extracted with EtOAc $(3 \times 10 \mathrm{~mL})$. The combined organic layers were dried over $\mathrm{MgSO}_{4}$ and concentrated. Flash chromatography of the residue on silica gel (25:1 hexanes/EtOAc) gave $2.8 \mathrm{mg}(15 \%)$ of dimer 29a, followed by $11.5 \mathrm{mg}(65 \%)$ of macrolide 29.

Data for 29: ${ }^{1} \mathrm{H}$ NMR 7.43-7.22 (m, 15), 5.45 (br dd, $\left.1, J=10.8,6.7\right), 5.32$ (dd, 1, $J=3.7,3.7), 5.20($ br d, $1, J=6.7), 4.50(\mathrm{dd}, 1, J=11.6,4.3), 4.38-4.34$ (m, 1), 3.76 (dddd, 1 , $J=11.0,11.0,3.7,3.7), 3.43(\mathrm{dd}, 1, J=8.6,5.5), 3.23-3.14(\mathrm{~m}, 1), 3.16(\mathrm{dd}, 1, J=8.6,8.6)$, $2.56(\mathrm{dd}, 1, J=11.6,11.6), 2.54-2.46(\mathrm{~m}, 2), 2.40-2.34(\mathrm{~m}, 1), 2.23(\mathrm{dd}, 1, J=11.6,4.3), 2.20$ $2.15(\mathrm{~m}, 1), 2.09(\mathrm{dd}, 1, J=12.8,3.7), 1.82(\mathrm{~s}, 3), 1.47(\mathrm{ddd}, 1, J=12.8,3.7,3.7), 1.44-1.40$ (m, 1), $0.86(\mathrm{~s}, 9), 0.02(\mathrm{~s}, 3), 0.00(\mathrm{~s}, 3)$; MS (MALDI) calculated for $\mathrm{C}_{41} \mathrm{H}_{51} \mathrm{ClO}_{5} \mathrm{NaSi}\left(\mathrm{MNa}^{+}\right) 709$, found 709 .

Data for dimer 29a: ${ }^{1} \mathrm{H}$ NMR 7.44-7.22 (m, 30), 5.45-5.32 (m, 4), 5.09 (dd, 2, $J=7.3$, 6.7), $4.71(\mathrm{dd}, 2, J=8.6,6.1), 4.22(\mathrm{ddd}, 2, J=9.8,5.5,5.5), 4.15-4.10(\mathrm{~m}, 2), 3.35(\mathrm{dd}, 2$, $J=9.8,5.5), 3.12(\mathrm{dd}, 2, J=9.8,5.5), 2.95-2.86(\mathrm{~m}, 2), 2.80-2.74(\mathrm{~m}, 2), 2.43-2.30(\mathrm{~m}, 6), 2.09$ - 
$2.03(\mathrm{~m}, 2), 1.90-1.85(\mathrm{~m}, 2), 1.80-1.70(\mathrm{~m}, 4), 1.61(\mathrm{~s}, 6), 0.83(\mathrm{~s}, 18),-0.05(\mathrm{~s}, 6),-0.06(\mathrm{~s}, 6)$; MS (MALDI) calculated for $\mathrm{C}_{82} \mathrm{H}_{102} \mathrm{Cl}_{2} \mathrm{O}_{10} \mathrm{NaSi}_{2}\left(\mathrm{MNa}^{+}\right)$1396, found 1397.

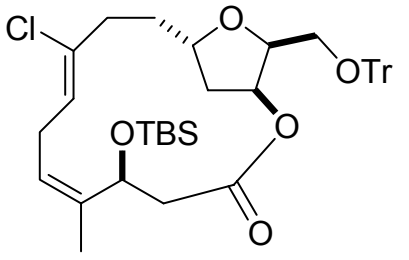

29

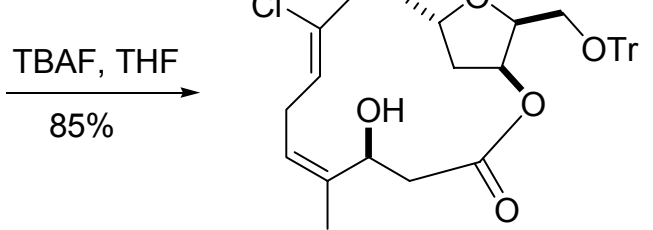

29b

(1S,5S,6Z,9Z,13S,15S)-10-chloro-5-hydroxy-15-[(triphenylmethoxy)methyl]-6-

methyl-2,14-Dioxabicyclo[11.2.1]hexadeca-6,9-dien-3-one (29b). TBAF (40 $\mu \mathrm{L}, 0.04$ mmol) was added to a solution of $29(11.2 \mathrm{mg}, 0.016 \mathrm{mmol})$ in THF $(1 \mathrm{~mL})$ and the solution was stirred at room temperature for $2 \mathrm{~h}$. The reaction was diluted with $\mathrm{Et}_{2} \mathrm{O}(5 \mathrm{~mL})$ and quenched with saturated $\mathrm{NH}_{4} \mathrm{Cl}(3 \mathrm{~mL})$. The organic layer was separated and the aqueous layer was extracted with $\mathrm{Et}_{2} \mathrm{O}(3 \times 5 \mathrm{~mL})$. The combined organic layers were dried over $\mathrm{MgSO}_{4}$ and concentrated. Flash chromatography of the residue on silica gel (5:1 hexanes/EtOAc) gave $7.9 \mathrm{mg}(85 \%)$ of alcohol 29b: ${ }^{1} \mathrm{H}$ NMR 7.43-7.21 (m, 15), 5.61 (br dd, 1, $\left.J=9.8,7.9\right), 5.37$ (dd, 1, $J=3.1,3.1$ ), $5.18(\mathrm{~d}, 1, J=7.3), 4.56(\mathrm{dd}, 1, J=11.6,3.7), 4.32(\mathrm{ddd}, 1, J=8.5,5.5,3.1), 3.77(\mathrm{dddd}, 1$, $J=11.6,11.6,3.7,3.7), 3.39(\mathrm{dd}, 1, J=8.5,5.5), 3.24-3.15(\mathrm{~m}, 1), 3.20(\mathrm{dd}, 1, J=8.5,8.5)$, $2.58(\mathrm{dd}, 1, J=11.6,11.6), 2.58-2.46(\mathrm{~m}, 2), 2.42-2.31(\mathrm{~m}, 1), 2.39(\mathrm{dd}, 1, J=11.6,3.7), 2.15$ $(\mathrm{ddd}, 1, J=12.8,5.5,5.5), 2.03(\mathrm{dd}, 1, J=12.8,3.7), 1.87(\mathrm{~s}, 3), 1.48(\mathrm{ddd}, 1, J=12.8,11.6$, 3.7), 1.42 (ddd, $1, J=11.6,11.6,5.5) ;{ }^{13} \mathrm{C}$ NMR 168.8, 143.8 (3 C), 137.5, 131.8, 128.6 (6 C), 127.8 (6 C), 127.4, 127.0 (3 C), 125.6, 86.5, 79.2, 76.1, 75.0, 65.9, 61.2, 39.9, 37.7, 34.8, 27.9, 26.3, 17.6; IR $\left(\mathrm{CH}_{2} \mathrm{Cl}_{2}\right) 3460,1732,1643 ;[\alpha]^{20}+10.3$ (c $\left.0.3, \mathrm{CHCl}_{3}\right) ; \mathrm{HRMS}$ (MALDI) calculated for $\mathrm{C}_{35} \mathrm{H}_{37} \mathrm{O}_{5} \mathrm{NaCl}\left(\mathrm{MNa}^{+}\right)$595.2227, found 595.2215. 


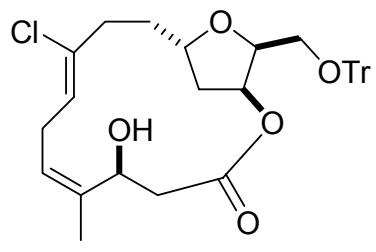

29b

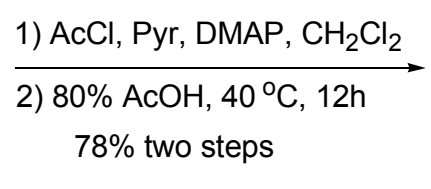

$78 \%$ two steps

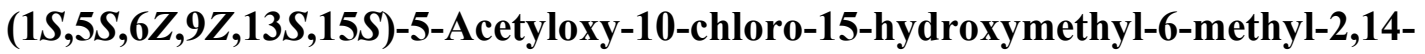

Dioxabicyclo[11.2.1]hexadeca-6,9-dien-3-one (30). Acetyl chloride (6.9 mg, $0.0873 \mathrm{mmol})$ was added to a solution of $\mathbf{2 9 b}(5 \mathrm{mg}, 8.73 \mu \mathrm{mol})$, pyridine $(6.8 \mathrm{mg}, 0.0873 \mathrm{mmol})$ and DMAP $(0.2 \mathrm{mg}, 1.75 \mu \mathrm{mol})$ in $\mathrm{CH}_{2} \mathrm{Cl}_{2}(0.5 \mathrm{~mL})$. The resulting mixture was stirred at room temperature for $1 \mathrm{~h}$. The reaction was quenched with $\mathrm{H}_{2} \mathrm{O}(1 \mathrm{~mL})$. The organic layer was separated and the aqueous layer was extracted with $\mathrm{Et}_{2} \mathrm{O}(3 \times 5 \mathrm{~mL})$. The combined organic layers were dried over $\mathrm{MgSO}_{4}$ and concentrated to give $5.0 \mathrm{mg}(95 \%)$ of crude product.

The crude product was treated with $80 \%$ HOAc in $\mathrm{H}_{2} \mathrm{O}(0.5 \mathrm{~mL})$ at room temperature and heated at $40^{\circ} \mathrm{C}$ for $12 \mathrm{~h}$. The reaction was quenched with saturated $\mathrm{NaHCO}_{3}(5 \mathrm{~mL})$. The aqueous layer was extracted with $\mathrm{Et}_{2} \mathrm{O}(3 \times 5 \mathrm{~mL})$ and the organic layers were dried over $\mathrm{MgSO}_{4}$ and concentrated. Flash chromatography of the residue on silica gel (2:1 hexanes/EtOAc) gave $2.5 \mathrm{mg}(78 \%)$ of alcohol 30: ${ }^{1} \mathrm{H}$ NMR $\left(\mathrm{CD}_{3} \mathrm{OD}\right) 5.76(\mathrm{dd}, 1, J=9.3,6.7), 5.69$ (br dd, 1 , $J=8.2,8.2), 5.33($ br d, $1, J=6.7), 5.26(\mathrm{dd}, 1, J=3.7,3.7), 4.15(\mathrm{ddd}, 1, J=6.7,6.7,3.7)$, 3.91 (dddd, $1, J=11.6,11.6,3.1,3.1), 3.69$ (dd, $1, J=11.6,6.7), 3.66$ (dd, $1, J=11.6,6.7$ ), 3.52-3.43 (m, 1), 2.77-2.74 (m, 2), 2.52-2.42 (m, 2), 2.32-2.28 (m, 2), 2.09 (dd, 1, J = 12.8, 3.1), $2.01(\mathrm{~s}, 3), 1.87(\mathrm{~s}, 3), 1.52(\mathrm{ddd}, 1, J=12.8,3.7,3.7), 1.46-1.40(\mathrm{~m}, 1) ;{ }^{13} \mathrm{C} \mathrm{NMR}\left(\mathrm{CD}_{3} \mathrm{OD}\right)$ $171.2,169.4,134.6,133.2,130.9,127.0,82.1,77.5,76.8,68.7,61.3,38.72,38.71,35.5$ 29.0, 27.7, 20.9, 18.5; IR $\left(\mathrm{CH}_{2} \mathrm{Cl}_{2}\right) 3417,1732 ;[\alpha]^{20}+10.7$ (c $\left.0.15, \mathrm{CHCl}_{3}\right)$. The ${ }^{1} \mathrm{H}$ NMR spectrum is identical to that provided by Prof. Kigoshi. 


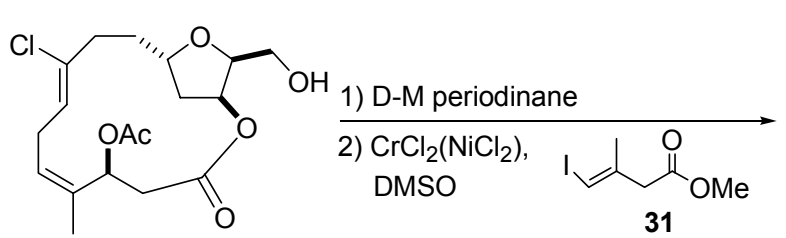

30

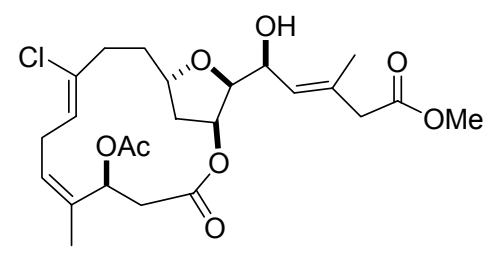

Haterumalide NA methyl ester (32)

Haterumalide NA Methyl Ester (32). Dess-Martin periodinane (12.3 mg, $29.0 \mu \mathrm{mol})$ was added to a solution of $\mathbf{3 0}(2.0 \mathrm{mg}, 5.38 \mu \mathrm{mol})$ in $\mathrm{CH}_{2} \mathrm{Cl}_{2}(1 \mathrm{~mL})$. The mixture was stirred at room temperature for $3.5 \mathrm{~h}$ and quenched with saturated $\mathrm{Na}_{2} \mathrm{SO}_{3}(5 \mathrm{~mL})$ and saturated $\mathrm{NaHCO}_{3}$ $(5 \mathrm{~mL})$. After stirring at room temperature for $1 \mathrm{~h}$, the resulting mixture was extracted with $\mathrm{Et}_{2} \mathrm{O}$ $(3 \times 5 \mathrm{~mL})$. The organic layers were dried over $\mathrm{MgSO}_{4}$ and concentrated to give aldehyde 2 (2 mg), which was used in the next experiment without purification.

A solution of aldehyde 2 (2 mg) and iodide $31(41.0 \mathrm{mg}, 0.170 \mathrm{mmol})$ in DMSO (0.5 mL) was added to $\mathrm{CrCl}_{2}$ containing $1 \% \mathrm{NiCl}_{2}(58 \mathrm{mg}, 0.472 \mathrm{mmol})$ under $\mathrm{N}_{2}\left(\mathrm{CrCl}_{2}\right.$ and $\mathrm{NiCl}_{2}$ were handled in a glove box). After stirring at room temperature for $20 \mathrm{~h}$, the reaction was diluted with $\mathrm{Et}_{2} \mathrm{O}(5 \mathrm{~mL})$ and poured into $\mathrm{H}_{2} \mathrm{O}(5 \mathrm{~mL})$. The aqueous layer was extracted with $\mathrm{Et}_{2} \mathrm{O}(3 \times 5 \mathrm{~mL})$ and organic layers were dried over $\mathrm{MgSO}_{4}$ and concentrated. Flash chromatography of the residue on silica gel (9:1 to 2:1 hexane/EtOAc) gave $0.7 \mathrm{mg}(30 \%)$ of product 32. Further purification by $\mathrm{HPLC}(\mathrm{C} 18,4.6 \times 250 \mathrm{~mm}, 80 \%$ aqueous $\mathrm{MeOH}, 1 \mathrm{~mL} / \mathrm{min}$, UV $215 \mathrm{~nm}$ ) gave haterumalide NA methyl ester (32) (ca. $0.5 \mathrm{mg}): \mathrm{CD}(\mathrm{MeOH}) \lambda_{\text {ext }} 219 \mathrm{~nm}(\Delta \varepsilon$ -0.8); ${ }^{1} \mathrm{H}$ NMR ( $\left.\mathrm{CD}_{3} \mathrm{OD}\right) 5.79$ (dd, $\left.1, J=11.4,4.6\right), 5.70$ (br dd, 1, $\left.J=9.6,6.4\right), 5.37$ (br d, 1, $J=8.5), 5.31($ br d, $1, J=6.7), 5.30(\mathrm{dd}, 1, J=3.7,3.7), 4.53(\mathrm{dd}, 1, J=8.5,8.5), 3.93(\mathrm{dddd}, 1$, $J=11.4,11.4,3.6,3.6), 3.90(\mathrm{dd}, 1, J=8.5,3.7), 3.67$ (s, 3), 3.49 (m, 1), 3.08 (s, 2), 2.81 (dd, 1, $J=11.5,4.6), 2.77(\mathrm{dd}, 1, J=11.5,11.4), 2.47(\mathrm{~m}, 2), 2.29(\mathrm{~m}, 2), 2.10(\mathrm{dd}, 1, J=12.8,3.6)$, $2.02(\mathrm{~s}, 3), 1.88(\mathrm{~s}, 3), 1.81(\mathrm{~d}, 3, J=1.3), 1.52(\mathrm{ddd}, 1, J=12.8,11.4,3.7), 1.39(\mathrm{~m}, 1)$. The ${ }^{1} \mathrm{H}$ NMR and CD spectra are identical to those reported by Prof. Kigoshi. ${ }^{5}$

\section{References and Notes}

(22) Berry, M. B.; Craig, D. Synlett 1992, 41.

(23) Slougui, N.; Rousseau, G. Synth. Commun. 1987, 17, 1. 
(24) Brussani, G.; Ley, S. V.; Wright, J. L.; Williams, D. J. J. Chem. Soc. Perkin Trans. 1 1986, 303.

(25) Bertolini, G.; Casagrande, C.; Norcini, G.; Santangelo, F. Synth Commun. 1994, 24, 1833.

(26) (a) Scialdone, M. A.; Johnson, C. R. Tetrahedron Lett. 1995, 36, 43. (b) Sliskovic, D. R.; Roth, B. D.; Wilson, M. W.; Hoefle, M. L.; Newton, R. S. J. Med. Chem. 1990, 33, 31. 